\title{
An Examination of Perception of Science and Art Centers' Teachers about Organizational Change and Organizational Dissent
}

\author{
Mahire Aslan \\ Inonu University, Malatya, Turkey \\ E-mail: mahire.aslan@inonu.edu.tr \\ Umit Dogan \\ Sakarya Provincial Directorate of National Education, Sakarya, Turkey \\ E-mail: doganumit18@hotmail.com
}

\begin{abstract}
This research is carried out to examine the level of perceptions of teachers working in science and art centers about organizational change and organizational dissent. The population of the research consisted 1755 teachers working in 137 science and art centers in Turkey during 2019-2020 academic year. The data of the research were gathered by Teachers' Attitude Scale for Organizational Cahnge scale developed by Kurşunoğlu and Tanrı̈ğen (2006) and Organizational Dissent Scale developed by Kassing (1998) and adapted to Turkish by Dagli (2015). In the data analysis process, SPSS was used. According to the results of the research, it was revealed that the perceptions of science and art centers' teachers about organizational change and organizational dissent were on the medium level and while they showed significant differences in terms of the variables of gender, professional seniority and working status; they did not make any meaningful difference regarding the variables of marital status and graduation level. Also, a positive, meaningful and intermediate relationship between organizational change and organizational dissent perceptions of teachers. Accordingly, taking the findings of the research into consideration, various suggestions were presented at the last part of the research.
\end{abstract}

Keywords: Organizational change, organizational dissent, Science and Art Center.

\section{Special Issue of Educational Sciences}

DOI: $10.7176 / J S T R / 6-06-09$

\section{Bilim ve Sanat Merkezi Öğretmenlerinin Örgütsel Değişim ve Örgütsel Muhalefet Algı Düzeylerinin İncelenmesi}

\section{Özet}

$\mathrm{Bu}$ araştırma Bilim ve Sanat Merkezlerinde (BİLSEM) çalışan öğretmenlerin örgütsel değişim ve örgütsel muhalefet algı düzeylerinin incelenmesi amacıyla yapılmıştır. Araştırmada ilişkisel tarama modeli kullanılmıştır. Araştırmanın çalışma evrenini 2019-2020 eğitim öğretim yılında 137 Bilim ve Sanat Merkezinde çalışan 1755 öğretmen oluşturmaktadır. Bu araştırmanın verileri, Kurşunoğlu ve Tanrı̈ğen (2006) tarafindan geliştirilen “'Öğretmenlerin Örgütsel Değişime İliş̧kin Tutum Ölçeği” ve Kassing (1998) tarafindan geliştirilip Dağlı (2015) tarafindan Türkçeye uyarlanan "Örgütsel Muhalefet Ölçeği” ile elde edilmiştir. Verilerin çözümlenmesi SPSS paket programı kullanılarak gerçekleştirilmiştir. Verilerin analizinde yüzde, frekans, aritmetik ortalama, standart sapma, t-Testi, One Way Anova, Tukey HSD testi, korelasyon analizi ve regresyon analizi teknikleri kullanılmıştır. Bilim ve Sanat Merkezi öğretmenlerin örgütsel değişim alg1 düzeyleri ile örgütsel muhalefet algı düzeyleri arasında ilişki olup olmadığı, varsa ilişkinin yönü ve derecesinin belirlenmesinde korelasyon analiz yapılmıştır. Araştırmanın bulguları, BİLSEM öğretmenlerinin örgütsel değişime yönelik algılarının orta düzeyde olduğunu, bu algıların cinsiyet, çalışma durumu ve kıdem değişkenleri açısından anlamlı bir farklılık gösterdiğini; medeni durum ile 
öğrenim düzeyi değişkenleri açısından ise anlamlı bir farklılık göstermediğini ortaya koymuştur. BİLSEM öğretmenlerinin örgütsel muhalefet algılarının orta düzeyde olduğunu bu algıların cinsiyet, çalışma durumu ve kıdem değişkenleri açısından anlamlı bir farklılık gösterdiği; medeni durum ve öğrenim düzeyi değişkenleri açısından ise anlamlı bir farklılık göstermediği belirlenmiştir. Araştırma sonuçlarına göre BİLSEM'de çalışan öğretmenlerin örgütsel değişim ve örgütsel muhalefet algıları arasında orta düzeyde pozitif yönde ve anlamlı bir ilişki olduğu bulunmuştur. Buna göre, öğretmenlerin örgütsel değişim algıları, örgütsel muhalefet algılarındaki değişimin \%62'sini açıkladığı; öğretmenlerin örgütsel değişim algıları ile dikey muhalefet algıları arasında pozitif yönde ve orta düzeyde bir ilişki sergilediği ve buna göre öğretmenlerin örgütsel değişim algıları, dikey muhalefet algılarındaki değişimin $\% 45$ 'ini açıkladığı; öğretmenlerin örgütsel değişim algıları ile yatay muhalefet algıları arasında pozitif yönde ve orta düzeyde bir ilişki sergilediği ve buna göre öğretmenlerin örgütsel değişim algıları, yatay muhalefet algılarındaki değişimin \%53'ünü açıkladığı bulunmuştur. Araştırmanın son bölümünde, ulaşılan sonuçlar dikkate alınarak çeşitli öneriler sunulmuştur.

\section{Anahtar Sözcükler: Örgütsel Değişim, Örgütsel Muhalefet, Bilim ve Sanat Merkezi}

\section{Giriş}

Yaşamını devam ettirebilmek için insanoğlu var olduğu günden beri çevresiyle sürekli bir etkileşim içinde olmuş ve bu etkileşim sonucunda birçok bilgi ve birikim elde etmiştir. Bu bilgi ve birikim toplumlar tarafindan, yetişmekte olan genç kuşaklara amaçlı olarak aktarılmaya çalışılmıştır. Amaçlı olarak yapılan bu aktarmalar kasıtlı kültürleme süreci olup bu süreç eğitim olarak tanımlanmıştır (Fidan ve Erden, 1994). Günümüzde gelişmiş ülkelerin kalkınmayı eğitimle sağladıkları, bunun için eğitime büyük yatırımlar yaptıkları bilinmektedir. Kalkınmanın sağlanması ancak toplumun değiş̧im bilincine ulaşmasına bağlıdır ve bunun ilk koşulu ise eğitimdir. Kalkınmayı etkileyen insan girdisi, diğer girdileri kullanan, etkinliklerin yönünü ve derecesini belirleyen, yönlendiren, karar verici değişken olduğundan önemi diğer girdilerden çok daha fazladır. Ekonomik kalkınmanın yeterli insan gücüne gereksinimi artık tartışılmaz bir gerçektir (Başar, 1996). Gereksinim duyulan insan gücünü sağlamak ise ancak eğitime yönelik çabalarla mümkün olur. Eğitim sisteminin bu denli önemli işlev ve görevlerini istenen biçimde yapabilmesi, bunları yapabilecek kapasite ve nitelikte örgütlenmesi ile mümkündür (Balcı, 2000).

\subsection{Bilim ve Sanat Merkezi}

Kasıtlı kültürlenme sürecinde çoğunluktan farklı bireyler için yeteneklerinin geliştirilmesi, bireyin kendine yeter hale gelmesi, topluma uyum sağlaması, hem kendi hem de içinde yaşadığ toplum için faydalı bireyler olması, farklılık ve çeşitliliklerin kaynaştırılması için gerçekleştirilen eğitim, özel eğitimdir (Ataman, 2011; Hornby, 2016). Her bireyin olduğu gibi, özel eğitime muhtaç tüm bireylerin de eğitim hakkı korunmalı ve geliştirilmelidir (Batu ve Kırcaali İftar, 2006). Özel eğitim hizmetlerinin korunması, geliştirilmesi ve yaygınlaştırılması dünyanın birçok ülkesinde çağdaşlaşma ölçüsü olarak görülmektedir (Cavkaytar ve Diken, 2005). Bu bağlamda Türkiye Cumhuriyeti Anayasasında 'Devlet durumları sebebiyle özel eğitime ihtiyacı olanları topluma yararlı kılacak tedbirleri alıı" ifadesi yer almaktadır ki bu ifade Türkiye Cumhuriyet Devleti'ni özel eğitim hizmetlerinin geliştirilmesinden sorumlu kılmıştır (T.C. Anayasası, 1982). Türkiye'de özel eğitime muhtaç bireylerin eğitimleri Milli Eğitim Bakanlı̆̆ı Özel Eğitim Hizmetleri Yönetmeliği kapsamında ya akranlarından ayrı ya da akranları ile birlikte gerçekleştirilmektedir (MEB, 2018). Yaratııılık, zekâ, liderlik, sanat veya özel akademik alanlarda yaşıtlarına göre daha iyi başarı gösterebilen bireyler de özel eğitime muhtaç bireyler olup bu bireyler özel yetenekli olarak tanımlanmaktadır. Dünya Sağlık Örgütüne (WHO) göre toplumun \%23'ünü özel yetenekli bireyler oluşturmaktadır. TÜIK verilerine göre 2017 yılsonu itibariyle 80 milyon 810 bin 525 olan Türkiye nüfusunun 22 milyon 883 bin 288 'ini çocuk nüfusu oluşturmaktadır. Bu çocuk nüfusunun 457.667 ile 686.499 'unun özel yetenekli çocuk olduğu tahmin edilmektedir. Özel yetenekli bireylerin bireysel yeteneklerinin farkında olması ve yeteneklerini geliştirmesi adına özel yetenekli bireylerin eğitimi de özel eğitim olarak değerlendirilmektedir (Leavitt, 2017). Milli Eğitim Bakanlı̆̆1 tarafindan bu özel yetenekli çocukların bilişsel, sosyal, fiziksel ve duygusal özelliklerinin geliştirilmesi, akademik gelişimlerinin desteklenmesi, yaratıcı düşünme becerilerinin geliştirilmesi ve performanslarının arttırılması için 1996 yılından itibaren Bilim ve Sanat Merkezleri (BILLSEM)

$\mathbf{1 1 5} \mid \mathrm{P}$ a g e

www.iiste.org 
kurulmuştur. Türkiye'de ilk BİLSEM Ankara ilinde Yasemin Karakaya Bilim ve Sanat Merkezi adıyla kurulmuş olup 2019 yll sonu itibariyle BİLSEM'ler 81 ilde 137 merkezde hizmet vermektedir. BİLSEM'lerde özel yetenekli öğrenciler, yeteneklerini geliştirerek kapasitelerini en üst düzeyde kullanmaları ve özgün projeler üretebilmeleri amacıyla robotik, kodlama, mekatronik, diksiyon ve hitabet, hızlı okuma teknikleri, liderlik, akıl oyunları, astronomi, filoloji, şehir kültürü, fotoğrafçılık, drama, sanat tarihi, masaüstü yayımcılık, veri madenciliği, bilimsel araştırma teknikleri, arkeoloji gibi atölyelerde etkinlik temelli ve uygulamalı eğitimler almaktadırlar. BİLSEM'lerde eğitim-öğretim hizmetlerinin yürütülmesinde; bireysel eğitim-öğretimin yapılması, eğitimlerin öğrencilerin devam ettikleri örgün eğitim kurumlarındaki programlara destek olacak şekilde planlanması, farklı ve özgün düşünebilmesi, çıkarımlarda bulunma ve bunları istişare ederek, tartışarak çalışmalarına yansıtma becerileri kazandırılması, problem çözme ve bağımsız karar verme becerileri kazandırılması esastır (MEB, 2016). Milli Eğitim Bakanlığı 2019-2020 eğitim öğretim yılı verilerine göre BİLSEM'lerde devam eden öğrenci sayıs1 40132 olup görev yapan öğretmen sayısı ise 1755'dir. Öğretmenlik mesleği; eğitim sektörü ile ilgili olan ekonomik, sosyal, bilimsel, kültürel ve teknolojik boyutlara sahip, mesleki formasyonu gerektiren ve alanda özel uzmanlık bilgi becerisini temel alan akademik çalışma ve profesyonel statüde bir uğraşı alanıdır ki bu boyutlar göz önüne alındığında özel yeteneklilerin eğitim öğretimlerinde görev alacak öğretmenlerin diğer öğretmenlerden bilgi, beceri ve yeterlilikler yönlerinden pozitif yönde farklı olmaları beklenmektedir (Dağlığlu, 2010). Bu yöndeki beklenti tüm öğrencilere eşit davranmak adına değil, farklı yetenekli öğrencilere adaletli davranmak adınadır (Roda, 2015). Özel yetenekli bireylerin yetiştirilmesinde görev alacak olan öğretmenlerde pozitif yönde farklılığın oluşturulması için 209 yılı itibariyle Türkiye'de biri devlet, dördü vakıf olmak üzere beş üniversitede lisans seviyesinde "Üstün Zekâlılar Öğretmenliği’” bölümleri mevcuttur. Bu bölümlerden mezun olan öğretmen adayları Milli Eğitim Bakanlığınca sınıf öğretmeni olarak ilkokullara atanmaktadır. Milli Eğitim Bakanlığı özel yetenekli öğrencilerin eğitimi için BİLSEM'lere Bakanlık bünyesinde görev yapan öğretmenler arasından belirli aralıklarla yayımlanan seçme ve atama kılavuzu doğrultusunda seçme ve atama yapmaktadır. BİLSEM'lere en son 08/06/2019 tarihinde öğretmen seçimi yapılmış olup on yedi farklı branşta başvuru alınmıştır. Milli Eğitim Bakanlığı tarafından BİLSEM'lere ataması yapılacak öğretmenler için sadece öğretmenlikte adaylı̆̆ kalkmış olmak ve başvuru yapacağı ilde kontenjan bulunması ön şartı getirilirken bunların yanında, yüksek lisans veya doktora yapmış olmak, alanıyla ilgili kongrelere katılmış olmak, kongrelerde bildiri sunmuş olmak, ulusal veya uluslararası projelerde görev almış olmak, hakemli dergilerde makale yayımlamış olmak, yabancı dil bilmek, kitap yazmış olmak, özel yetenekliler ile ilgili çalıştaylarda görev almış olmak gibi kriterler de ek puan olarak belirlenmiştir. Bu kriterlere göre ilinde branş bazında ilk üçe giren adaylar Milli Eğitim Bakanlığı tarafından mülakata tabi tutulmuş ve mülakat sonrasında uygun görülen adaylar Bilim ve Sanat Merkezlerine kadrolu öğretmenler olarak atanmıştır. Milli Eğitim Bakanlı̆̆ı, özel yetenekli öğrencilerin; , manevi ve kültürel değerlerini benimsemiş, millî, insani, ahlaki, hür ve bilimsel düşünme gücüne sahip; bilimsel düşüncelerle estetik değerleri birleştiren, lider, yapıcı ve ülke kalkınması için gerekli bilince sahip olan, üretken, problem çözen, kendini gerçekleştirmiş bireyler olarak yetiştirilmesi ile ilgili görev ve sorumlulukları BİLSEM öğretmenlerine yüklemişstir (MEB, 2016). Bu görev ve sorumlulukların yerine getirilmesi için BİLSEM'lerin ve BİLSEM öğretmenlerinin sürekli bir değişim ve yenileşme içinde olmaları gerektiği açıktır.

\section{2. Örgütsel Değişim}

Kökeni Herakletios, Eflatun ve Farabi gibi düşünürlere kadar uzanan değişim; yenileşme, reform, sslah ve yeniden yapılandırma gibi günlük yaşantımızda sıklıkla karşılaştığımız ve kullandığımız kavram haline gelmiştir (Özdemir ve Cemaloğlu, 2017). Yunan fillozofu Herakleitos'un 'güneş her gün yenidir" ve "değişmeyen tek şey, değişimdir" sözleri Çalık'a (2003) göre hem bir koşul hem de bir süreci barındırmaktadır. Değişime koşul olarak bakıldığında insanları etkileyen ancak onların dışında gerçekleşen, süreç olarak bakıldığında ise bireyi içine alan aktif bir alandır. Türk Dil Kurumu (2018) değişimi, belli bir zaman dilimi içindeki değişikliklerin bütünü olarak tanımlarken, Helvacı (2005) ise değişimi bir durumdan farklı bir duruma geçen, yönü doğrultusu ve yargısı olmayan, kendiliğinden olabileceği gibi kişiler tarafindan da harekete geçirilen (planlı ya da plansız), istendik planlı yönde gerçekleşmesi halinde olumlu, aksi takdirde olumsuz olarak nitelendirilen bir süreç olarak tanımlamıştır. Örgütsel değişim ise örgütsel faaliyetlerle ilgili tüm hususlarda mevcut durumdan

$\mathbf{1 1 6} \mid \mathrm{P}$ a g e

www.iiste.org 
yeni/farklı bir konuma gelmeyi tanımlamaktadır (Koçel, 2010). Örgütsel değişimde, örgütlerin yapısı, hedefleri, politikaları, ödül cezası sistemleri, tutumları, davranışları, becerileri ve beklentileri, kullanılan makine ve teçhizatın teknolojisinde meydana gelen değişiklikler örgütsel değişikliğe neden olan iç kuvvetlerdir. Mali kaynaklar ve koşullar, personel, pazarlama ise dış kuvvetler arasındadır (Lawyer, 2007). Örgütsel değişim türlerini Sabuncuoğlu ve Tüz (2001) şöyle ifade etmişlerdir: Teknolojik değişiklik (kullanılan araç ve gereç değişimi), personelde değişiklik (insan faktörü üzerindeki değişiklikler) ve süreç ve yöntemlerde değişikliktir (yapılan işin yönteminde yapılan değişiklikler). Ayrıca değişimin sebeplerine bağlı olarak ortaya çıkan örgütsel değişim türleri de mevcuttur (Özdemir ve Cemaloğlu, 2017). Bunlar şöyle ifade edilebilir: Dar kapsamlı/geniş kapsamlı değişim, Plansız/planlı değişim, Ani değişim/zamana yayılmış, Reaktif değişim/proaktif (öngörücü), Pasif/aktif değişim, Mikro/makro değişim, Köklü değişim/iyileştirme şeklide aşamalı değişim. Bütün örgütler gibi okullar da değişim sürecinden etkilenmektedir. Bu bağlamda düşünüldüğünde, okullar açısından da değişim kaçınılmaz bir olgudur (Beycioğlu ve Aslan, 2010). Eğitimsel değişme için en uygun birim; öğrencileri, öğretmenleri ve müdürü ile okul örgütüdür. Okullar açısından bakıldığında örgütsel değişim bir norma dönüşmüştür. Uyumlu, esnek ve değişime açık okulların kendi emsallerine oranla daha başarılı olduğunu bulgulayan araştırmalar vardır (Lunenburg ve Ornstein, 2013; Schlechy, 2011). 1980'lerin sonlarından bu yana, eğitim ortamında yapılan çeşitli değişiklikler neticesinde dünyanın birçok yerinde okul reformları ortaya çıkmıştır. Eğitimden yüksek beklentiler, öğretim ve yönetim süreçlerinde üstünlük ve yaratıcılık gereksinimleri, özellikle bilgi teknolojilerindeki gelişmeler, örgütsel yönetimde insanı ön plana eğilimler, özelleştirme, yerelleştirme ve küreselleşme gibi etkenler, eğitimde değişimi kaçınılmaz hale getirmektedir. Etkili okul araştırmalarının, okula dayalı yönetim anlayışının, okullarda kalkınma ve planlamaya yoğunlaşmanın, eğitimde kalite güvencesini artırmanın, yeni müfredat programlarının, yenileşmeye uygun bilgi teknolojilerinin, eğitim reformları ve okulu yeniden yapılandırma girişimlerinin, okulda değişime ve yenileşmeye örnek uygulamalar olduğu söylenebilir. Bu uygulamalarda örnek bir öğretmen, program ve okulun nasıl olacağ 1 sorusuna verilecek yanıt kritik bir önem taşımaktadır (Helvacı, 2005). Bu sorunun yanıtı, değişimi destekleyen tüm okul toplumunun gönüllü katılım ve katkısını içermektedir. Eğitimde değişimin başarısı için, değişim uygulayıcılarının değişime karşı olumsuz tavır sergilememeleri ve değişimin başarısına inanmaları gerekmektedir (Çalık, 2003). Değişime karşı olumsuz tavırların nedeni genellikle söz konusu değişimin o ana kadar rahatlıkla karşılanan bireysel ihtiyaçların karşılanmasını sekteye uğratma potansiyeli, bilinmeyene karşı olan korku, bireyin hali hazırda elinde olan güç ve etkileme alanını tehdit etmesi, bireylerin var olan bilgi ve becerinin yeni süreçte yetersiz veya eski kalmasından duyulan endişe, örgütün genel yapısı ve kaynak yetersizliğidir (Güçlü ve Şehitoğlu, 2006).

\section{3. Örgütsel Muhalefet}

Örgüt içerisinde ortaya çıkan görüş ayrılıkları durumu örgütsel muhalefet (organizational dissent) olarak tanımlanmaktadır (Kassing, 2008). Örgütsel muhalefeti Wright (2013) ise bir veya birden fazla örgüt üyesinin öneriler dile getirdiği, açıkça karşı çıktığı, yönetimsel emirlere karşıt olarak fikirler sunduğu durum olarak tanımlamaktadır. Örgüt üyelerince ortaya konulan muhalif davranışların birçok nedeni vardır. Örgütsel muhalefetin ortaya çıkmasında başlatıcı olay (triggering event) denilen durumun ortaya çıkması gereklidir. Örgütsel muhalefete yol açan tetikleyici olayları Garner (2009) dokuz başlık altında toplamıştır: Örgütsel kaynaklar, performans değerlendirme, örgütsel değişme, etkisizlik, görev ve sorumluluklar, etik ve örgüt üyelerine yönelik davranışlar, zararın engellenmesidir. Örgüt içinde oluşan uygulamalar karşısında işgörenler ilişkisel, bireysel ve örgüt değişkenlerine bağlı farklı tarzda muhalif davranışlar sergileyebilir. Örgütsel kimi durum, uygulama ya da olayı bir problem olarak algılayan ve kendini sorumlu hisseden örgüt üyesinin, çeşitli protesto ya da karşı gelme davranışlarını iki alt başlıkta inceleyebiliriz. Birinci olarak haber uçurma davranışı (whistleblowing), ikincisi ise sorunun, başta üst yöneticiler olmak üzere örgüt içindeki diğer sorumlulara iletilmesi davranışıdır (Davids ve Waghid, 2017). Haber uçurma, McMurray’a (2007) göre çalışan ya da görevden ayrılan kişinin, işveren bilgisi dâhilinde gelişen, yasa ya da etik dışı uygulamaları sızdırması olayıdır. Bu sıdırma davranışın sergilenmesine sigortasız işçi çalıştırma, usulsüz vergi uygulamaları, cinsel veya sosyal taciz, mobbing gibi uygulamalar neden olan olabilmektedir. Örgüt üyelerinin görüş ayrılığına düştükleri bazı örgütsel uygulamaları üstlerine doğrudan veya dolaylı olarak ifade etmeleri dikey muhalefet olarak adlandırılmaktadır (Kassing ve Armstrong, 2002). Örgüt üyeleri dikey muhalefet davranışlarını belirli bir amaç için sergilemektedirler. Örgüt üyelerinin bu tür davranış

$\mathbf{1 1 7} \mid \mathrm{P}$ a g e

www.iiste.org 
sergilemelerinin en önemli sebebi üyelerin yöneticiler ile yakın kişisel ilişkiler kurmak ve görevini iyi yapmak sureti ile yöneticinin gözüne girmeye çalışmaktır. Örgüt üyelerinin muhalif görüşlerini örgüt içindekilere aktarmasına ise yatay muhalefet denilmektedir. Bu muhalefet türü diğer üyeleri kendilerine rakip görmesinden kaynaklanmaktadır. Bazı durumlarda örgüt üyeleri muhalif görüşlerini açıktan belirtmektedir. Uygulamalara sessiz kalmayarak diğer üyelere aktarmaktadır. Yatay muhalefet gösteren örgüt üyeleri örgüt içinde güvende olduklarını düşünebilmektedir. Örgüt içi yakın ilişkilere sahip olmaları ve belirli uzmanlıkları olmaları güçlü yanları olabilmektedir. Kişisel çıkarları için muhalefet davranışı göstermektedirler. Kendilerini dinleyecek birilerini bulunca muhalif görüşlerini paylaşmaktadırlar (Kassing, 2008). Örgüt üyeleri kimi zaman muhalif görüşlerini açık bir şekilde dile getirmekten sakınabilirler. Bu sakınma durumunda farklı bir arayışa girerek dikey ya da yatay muhalefet stratejisi yerine iş dışındaki arkadaşlarına, akrabalarına veya yakınlarına muhalif görüşlerini anlatmaktadırlar. Bu muhalefet biçimine de yer değiştirmiş muhalefet (displaced dissent) adı verilmektedir (Kassing ve Avtgis, 2001). Bu tarz muhalefet örgüt içinde kaygı taşıyan işgörenlerin sergilediği muhalif davranışlarıdır. Üyeler muhalefet tarzlarının veya kimliklerinin açığa çıkmasını istemeyebilirler. Daha çok miting ve gösteri gibi toplu eylemlerde gösterirler. Çalı̧̧anlar örgütsel muhalefeti dört farklı etki stratejisi ile gösterebilmektedir. Bu stratejiler ilişkisel etki stratejisi, üstünlük-bağl1lık stratejisi, bireysel etki stratejisi ve örgütsel özdeşleşme stratejisidir (Kassing, 1998). Iliş̧kisel etki stratejisi; bu strateji örgüt içindeki ilişkilerin niteliği ve türünü kapsar. Bu strateji ile çalışanlar örgütte ilişki temelli strateji geliştirme uğraşındadırlar. Çalışanlar düşüncelerini başkalarının yanında bildirmekten çekinirler. Eğer ilişkinin devam etmesi gerekiyorsa bunun tek yolunun sessiz kalmak olduğunu düşünürler. Bu stratejide benzer gruplarla ters düşmemeye, onlarla uyumlu olma yönünde bask1 hissedilir. Söz konusu gruplara ters düşme korkusu, görünüşte fikir birliği varmış izlenimi oluştursa da esasen gizli bir muhalefet anlayışı derinden işlemeye devam eder (Roberto, 2006). Üstünlük - bağllllk stratejisi; örgütsel muhalefette bu tür bir strateji işgörenlerle yöneticiler arasında samimi ilişkilere dayalı bir stratejiyi ifade eder. Bu strateji ile çalışanlar açık muhalefet gösterir ki bu tür bir stratejinin benimsenmesinde örgütsel kararlara katkıda bulunabilme firsatlarının olduğu, çalışanların fikirlerine değer verildiğini ve serbestçe inisiyatif geliştirme konusundaki algılar önemli rol oynar. Eğer çalışan yöneticisi ile samimi ilişki geliştiremezse gizli muhalefet yöntemini benimser. Bu tür çalışanlar fikirlerini beyan edebilmeleri için örgütte uygun bir ortamın olmadığına inanırlar (Kassing, 2009). Bireysel etki stratejisi; bu strateji çalışanların her türlü istek, çaba ve yeteneklerini gönüllü olarak örgüt için kullanmalarını kapsar. Bu stratejiyi benimseyen çalışanlar iç denetimli olup kontrol odakları daha çok içte olan insanlardır. Bu tarz iç denetim yönelimli çalışanlar daha çok kaderci ve istenilen sonuca ulaşmak için mutlak suretle harekete geçmek gerektiğine inanan insanlardır (Robbins, 2005). Örgütsel özdeşleşme stratejisi; bu strateji, işgörenin örgütüyle özdeşleşme ve yürek teması kurma ölçüsüne göre örgütsel muhalefet yapma biçiminin farklı olacağını ileri sürer. Bu strateji ile çalışanın muhalefet tarzı kişinin örgütle özdeşleşme derecesine göre değişmektedir. Çalışan ne kadar çok örgütle özdeşleşirse o kadar yapıcı tarzda muhalefet stratejisini seçmektedir. Eğer çalışan söz hakkının önemsendiğini düşünürse çok açık muhalefet yöntemini benimserken, örgütün misyon, vizyon, amaç ve hedeflerini benimsemediği zaman yıkıcı ve gizli muhalefete yönelmektedir (Kassing, 2001). Çalı̧anlar muhalefet etmeyi bir politika haline getirdikleri zaman başlıca beş tür davranış stratejisi geliştirirler. Bunlar; tekrarlama, gerçeğe dayalı doğrudan müracaat, çözüm sunma, yalan söyleme ve istifa tehdidini kullanmadır (Kassing, 2009). Bilim ve Sanat Merkezlerinde gerçekleştirilen eğitim hizmetleri düşünüldüğünde, bu hizmetlerin etkili bir şekilde sürdürülmesinde çalışanların örgütsel değişim ve örgütsel muhalefet algısı oldukça önemlidir. Bu bağlamda yapılan çalışmanın amacı Bilim ve Sanat Merkezlerinde çalışan öğretmenlerin örgütsel değişim ile örgütsel muhalefet algı düzeylerini belirlemektir.

\section{Yöntem}

\subsection{Araştırma Modeli}

$\mathrm{Bu}$ araştırmada ilişkisel tarama modeli kullanılmıştır. İlişsileri ve bağlantıları inceleyen araştırma, çoğunlukla ilişkisel araştırma olarak adlandırılır (Büyüköztürk, Çakmak, Akgün, Karadeniz ve Demirel, 2008). İlişkisel tarama modelleri, iki ve daha çok sayıdaki değişken arasında birlikte değişim varlığını ve/veya derecesini belirlemeye yarayan bir araştırma modelidir. Bu tür bir düzenlemede, aralarında ilişki aranacak değişkenler, ayrı ayrı sembolleştirilir. Ancak bu sembolleştirme, ilişkisel bir çözümlemeye olanak verecek şekilde yapılmak zorundadır (Karasar, 2007).

$\mathbf{1 1 8} \mid \mathrm{P}$ a g e

www.iiste.org 


\section{2. Çalışma Grubu}

Araştırmanın evrenini 2019-2020 eğitim öğretim yılında Bilim ve Sanat Merkezlerinde çalışan 1755 öğretmen oluşturmaktadır. Araştırmacının evrenin tamamına kolaylıkla ulaşabilmesi nedeniyle çalışmada evrenden örneklem alma yoluna gidilmemiştir. Araştırmacı tarafindan hazırlanan veri toplama formları Bilim ve Sanat Merkezlerinde çalışan 1755 öğretmenin tamamına e-posta ile gönderilmiş ve belirli bir takvim aralığında doldurmaları istenmiştir. Formlar 458 öğretmen tarafindan eksiksiz doldurulmuş ve analizler için bu sayı esas alınmıştır.

\subsection{Veri Toplama Araçları}

Araştırmada veri toplamak amaciyla ' Kişisel Bilgi Formu” ile birlikte “'Öğretmenlerin Örgütsel Değişime İlişkin Tutum Ölçeği (ÖÖDİTÖ)" ve "Örgütsel Muhalefet Ölçeği (ÖMÖ)” olmak üzere iki tane ölçek kullanılmıştır. Kişisel Bilgi Formu: Araştırmaya katılan öğretmenlerin demografik özelliklerinden cinsiyet, medeni durum, öğrenim düzeyi, çalışma durumu ve kıdem durumunu belirlemek amacıyla araştırmacı tarafından hazırlanmıştır. Öğretmenler bu formda kendileri için uygun olan seçeneği işaretlemişlerdir. Öğretmenlerin Örgütsel Değişime İlişkin Tutum Ölçeği: Kurşunoğlu ve Tanrıöğen (2006) tarafindan geliştirilen " Öğretmenlerin Örgütsel Değişime İlişkin Tutum Ölçeği” 59 maddeden oluşmaktadır. Ölçekte 5'li Likert tip bir skala kullanılmıştır. Ölçek toplam 59 soru, beş alt boyuttan oluşmaktadır. Değişme ihtiyacının belirlenmesi boyutu 8 soru, değişmenin planlanması boyutu 19 soru; değişmenin uygulanması boyutu 9 soru; değişmenin değerlendirilmesi boyutu 8 soru; değişmenin felsefesi boyutu 15 soru ile ölçülmektedir. Kurşunoğlu ve Tanrı̈ğen (2006), “Öğretmenlerin Örgütsel Değişime İlişkin Tutum Ölçeği” nin güvenirliğini belirlemek üzere bir ön uygulama yapmış ve ölçekte Reliability Analysis-Scale (Alpha) testi uygulamıştır. Bu uygulama sonucunda güvenirlik derecesi düşük çıkan maddelerde gerekli düzenlemeleri yapıp tekrar uygulayarak ölçeğin güvenirlik derecesi ,94 bulunmuştur. Ölçeğin alt boyutlarından değişme ihtiyacının belirlenmesi boyutunun güvenirlik derecesi ,64; örgütsel değişmenin planlanması boyutunun güvenirlik derecesi ,82; örgütsel değişmenin uygulanması boyutunun güvenirlik derecesi ,71; örgütsel değişmenin değerlendirilmesi boyutunun güvenirlik derecesi ,80; örgütsel değişmenin felsefesi boyutunun güvenirlik derecesi ise ,78 bulunmuştur. Araştırmada BİLSEM'de çalışan öğretmenlerin örgütsel değişime ilişkin algılarını belirlemek için kullanılan ölçme aracının güvenirlik çalışması tekrar yapılmış olup, ölçeğin alt boyutlarındaki Cronbach Alpha değeri değişme ihtiyacının belirlenmesi boyutu için ,77; örgütsel değişmenin planlanması boyutu için ,87, örgütsel değişmenin uygulanması boyutu için ,89; örgütsel değişmenin değerlendirilmesi boyutu için .81, örgütsel değişmenin felsefesi boyutu için ,79 bulunurken, ölçeğin tamamı için ise ,91 olarak bulunmuştur. Örgütsel Muhalefet Ölçeği: Ölçek Kassing (1998) tarafindan yayımlanan üç boyutlu ve 24 maddeli bir ölçme aracı olup yine Kassing tarafindan 2000 yılında revize edilerek 18 maddeli bir ölçme aracına dönüştürülmüştür. Ölçek Dağl1 (2015) tarafindan Türkçeye uyarlanmış ve güvenirliğgi, Cronbach Alpha iç tutarlık katsayısı ve test-tekrar test tekniği ile belirlenmeye çalışılmıştır. Ölçeğin bütünü için tutarlık katsayısı ,84 olarak hesaplanmıştır. Birinci alt boyut olan "Dikey Muhalefet" iç tutarlık katsayısı ,79; ikinci faktör olan "Yatay Muhalefet" için ise, ,82 olarak saptanmıştır. Ölçek 15 maddeden oluşmakta dikey muhalefet boyutu 8 soru, yatay muhalefet boyutu ise 7 soru ile ölçülmektedir. Araştırmada BİLSEM'de çalışan öğretmenlerin örgütsel muhalefet algılarını belirlemek için kullanılan ölçme aracının güvenirlik çalışması tekrar yapılmış olup, ölçeğin alt boyutlarındaki Cronbach Alpha değeri dikey muhalefet boyutu için ,75; yatay muhalefet boyutu için ,76 bulunurken, ölçeğin tamamı için ise, 84 olarak bulunmuştur.

\subsection{Verilerin Analizi}

Toplanan veriler SPSS 18.0 istatistik paket programına kaydedilmiş ve verilerle ilgili betimsel istatistikler çıkarılmıştır. Verilerin analizinde yüzde, frekans, aritmetik ortalama, standart sapma, t-Testi, One Way Anova, Tukey HSD testi, korelasyon analizi ve regresyon analizi teknikleri kullanılmıştır. Bilim ve Sanat Merkezi öğretmenlerin örgütsel değişim algı düzeyleri ile örgütsel muhalefet alg1 düzeyleri arasında ilişki olup olmadığı, varsa ilişkinin yönü ve derecesinin belirlenmesinde korelasyon analiz yapılmıştır. Ölçekler arasındaki korelasyon ilişkisinin değerlendirilmesinde 0.70-1.00 arası yüksek; 0.30-0.69 arası orta; 0.000.29 arası düşük düzey ilişki olarak ifade edilmiştir (Büyüköztürk ve ark., 2008). Örgütsel değişimin öğretmenlerin örgütsel muhalefetleri üzerindeki etkisini kestirmek amacıyla basit doğrusal regresyon tekniğine başvurulmuş olup, sayıltılar test edildiğinde çıktı değişkeninin nicel ve sınırsız olduğu hataların normal dağılım gösterdiği tespit edilmiştir.

$119 \mid \mathrm{P}$ a g e

www.iiste.org 


\section{Bulgular}

\subsection{BİLSEM Öğretmenlerinin Örgütsel Değișmeye İlişkin Tutum Düzeyleri}

Öğretmenlerin örgütsel değişmeye ilişkin tutum düzeylerinin ortalama puanları açısından incelenmesi Tablo 1'de gösterilmiştir.

Tablo 1. Örgütsel Değişime İlişskin Tutum Ölçeği ve Ölçeğin Alt Boyutlarına İle İlgili Analiz Sonuçları

\begin{tabular}{|l|c|c|c|c|}
\hline \multicolumn{1}{|c|}{ Değişkenler } & N & X & Ss & Madde Sayıs1 \\
\hline Değişme İhtiyacının Belirlenmesi & 229 & 3,41 &, 85 & 8 \\
\hline Değişmenin Planlanması & 229 & 3,46 &, 90 & 19 \\
\hline Değişmenin Uygulanması & 229 & 3,48 &, 87 & 9 \\
\hline Değişmenin Değerlendirilmesi & 229 & 3,42 &, 81 & 8 \\
\hline Değişimin Felsefesi & 229 & 3,43 &, 83 & 59 \\
\hline $\begin{array}{l}\text { Örgütsel Değişime İlişkin Tutum } \\
\text { Ölçeği }\end{array}$ & 229 & 3,44 &, 81 & 15 \\
\hline
\end{tabular}

Tablo 1 incelendiğinde BİLSEM öğretmenlerinin örgütsel değişime ilişkin tutum düzeylerinin aritmetik ortalamalarının $\overline{\mathrm{X}}=3,44$ ve standart sapmasının $\mathrm{Ss}=, 81$ olduğu görülmektedir. Örneklem grubunun değişme ihtiyacının belirlenmesi alt boyutu tutum düzeyinin aritmetik ortalamasının $\bar{X}=3,41$ olduğu, değişmenin planlanması alt boyutu tutum düzeyinin aritmetik ortalamasının $\bar{X}=3,46$ olduğu, değişmenin uygulanması alt boyutu tutum düzeyinin aritmetik ortalamasının $\bar{X}=3,48$ olduğu, değişmenin değerlendirilmesi alt boyutu tutum düzeyinin aritmetik ortalamasının $\bar{X}=3,42$ olduğu, değişmenin felsefesi alt boyutu tutum düzeyinin aritmetik ortalamasının 3,43 olduğu gözlenmektedir.

\subsection{BİLSEM Öğretmenlerinin Cinsiyetlerine Göre Örgütsel Değişmeye İlişkin Tutum Düzeyleri}

BİLSEM öğretmenlerinin cinsiyetlerine göre örgütsel değişmeye ilişkin tutum düzeyleri tablo 2'de gösterilmiştir.

Tablo 2. BİLSEM Öğretmenlerinin Örgütsel Değişime İlişkin Tutum Düzeylerinin Cinsiyet Değişkenine Göre t-Testi Sonuçları

\begin{tabular}{|c|c|c|c|c|c|c|c|}
\hline Değişkenler & Cinsiyet & $\mathrm{N}$ & $\mathrm{X}$ & Ss & $\mathrm{t}$ & $\mathrm{Sd}$ & $\mathrm{p}$ \\
\hline \multirow{2}{*}{$\begin{array}{l}\text { Değişme İhtiyacının } \\
\text { Belirlenmesi }\end{array}$} & Kadın & 94 & 2,74 & ,68 & \multirow{2}{*}{$-13,13$} & \multirow{2}{*}{227} & \multirow{2}{*}{, $000^{*}$} \\
\hline & Erkek & 135 & 3,88 & ,62 & & & \\
\hline \multirow{2}{*}{$\begin{array}{l}\text { Değişmenin } \\
\text { Planlanması }\end{array}$} & Kadın & 94 & 2,80 & ,69 & \multirow{2}{*}{$-11,47$} & \multirow{2}{*}{227} & \multirow{2}{*}{, $000^{*}$} \\
\hline & Erkek & 135 & 3,91 & ,74 & & & \\
\hline \multirow{2}{*}{$\begin{array}{l}\text { Değişmenin } \\
\text { Uygulanması }\end{array}$} & Kadın & 94 & 2,71 &, 74 & \multirow{2}{*}{$-16,49$} & \multirow{2}{*}{227} & \multirow{2}{*}{, $000^{*}$} \\
\hline & Erkek & 135 & 4,02 & ,45 & & & \\
\hline \multirow{2}{*}{$\begin{array}{l}\text { Değişmenin } \\
\text { Değerlendirilmesi }\end{array}$} & Kadın & 94 & 2,78 & ,75 & \multirow{2}{*}{$-13,30$} & \multirow{2}{*}{227} & \multirow{2}{*}{, $000^{*}$} \\
\hline & Erkek & 135 & 3,87 & ,48 & & & \\
\hline \multirow[t]{2}{*}{ Değişimin Felsefesi } & Kadın & 94 & 2,78 & ,74 & \multirow{2}{*}{$-12,75$} & \multirow{2}{*}{227} & \multirow{2}{*}{, $000^{*}$} \\
\hline & Erkek & 135 & 3,88 & ,55 & & & \\
\hline \multirow{2}{*}{$\begin{array}{l}\text { Örgütsel Değişime } \\
\text { İlişkin Tutum } \\
\text { Ölçeği }\end{array}$} & Kadın & 94 & 2,77 & ,68 & \multirow{2}{*}{$-14,47$} & \multirow{2}{*}{227} & \multirow{2}{*}{, $000^{*}$} \\
\hline & Erkek & 135 & 3,91 &, 50 & & & \\
\hline
\end{tabular}

$* \mathrm{p}<, 05$ 
Tablo 2 incelendiğinde BİLSEM öğretmenlerinin örgütsel değişime ilişkin tutum düzeylerinin cinsiyet faktörüne göre anlamlı bir farklılık gösterip göstermediğini belirlemek amacıyla bağımsız t-testi yapılmış olup BİLSEM öğretmenlerinin tüm ölçekteki değişime ilişkin tutum düzeyleri öğretmenlerin cinsiyetlerine göre anlamlı şekilde farklılık gösterdiği görülmektedir $[\mathrm{t}(227)=-14,47 ; \mathrm{p}<, 05]$. Erkek öğretmenlerin değişime ilişkin tutum düzeyleri kadın öğretmenlere göre anlamlı şekilde daha yüksek bulunmuştur. Aynı şekilde tüm alt boyutlarda erkek öğretmenlerin değişime ilişkin tutum düzeylerinin kadın öğretmenlere göre anlamlı şekilde daha yüksek olduğu bulunmuştur.

\subsection{BİLSEM Öğretmenlerinin Medeni Durumlarına Göre Örgütsel Değişmeye İlişkin Tutum Düzeyleri}

BİLSEM öğretmenlerinin medeni durumlarına göre örgütsel değişmeye ilişkin tutum düzeyleri tablo 3 'te gösterilmiştir.

Tablo 3. BİLSEM Öğretmenlerinin Örgütsel Değişime İlişkin Tutum Düzeylerinin Medeni Durum Değişkenine Göre t-Testi Sonuçları

\begin{tabular}{|c|c|c|c|c|c|c|c|}
\hline Değişkenler & $\begin{array}{l}\text { Medeni } \\
\text { Durum }\end{array}$ & $\mathrm{N}$ & $\mathrm{X}$ & Ss & $\mathrm{t}$ & $\mathrm{Sd}$ & $\mathrm{p}$ \\
\hline \multirow{2}{*}{$\begin{array}{l}\text { Değişme } \\
\text { İhtiyacının } \\
\text { Belirlenmesi }\end{array}$} & Bekâr & 99 & 3,53 & ,89 & \multirow[b]{2}{*}{1,18} & \multirow[b]{2}{*}{227} & \multirow[b]{2}{*}{, $04 *$} \\
\hline & Evli & 130 & 3,32 & ,82 & & & \\
\hline \multirow{2}{*}{$\begin{array}{l}\text { Değişmenin } \\
\text { Planlanması }\end{array}$} & Bekâr & 99 & 3,51 & 1,16 & \multirow{2}{*}{, 79} & \multirow{2}{*}{227} & \multirow{2}{*}{,42 } \\
\hline & Evli & 130 & 3,41 & ,64 & & & \\
\hline \multirow{2}{*}{$\begin{array}{l}\text { Değişmenin } \\
\text { Uygulanması }\end{array}$} & Bekâr & 99 & 3,49 &, 88 & \multirow{2}{*}{, 07} & \multirow{2}{*}{227} & \multirow{2}{*}{, 73} \\
\hline & Evli & 130 & 3,48 & ,87 & & & \\
\hline \multirow{2}{*}{$\begin{array}{l}\text { Değişmenin } \\
\text { Değerlendirilmesi }\end{array}$} & Bekâr & 99 & 3,44 & ,82 & \multirow{2}{*}{, 32} & \multirow{2}{*}{227} & \multirow{2}{*}{,94 } \\
\hline & Evli & 130 & 3,41 &, 80 & & & \\
\hline \multirow{2}{*}{$\begin{array}{l}\text { Değişimin } \\
\text { Felsefesi }\end{array}$} & Bekâr & 99 & 3,47 & 91 & \multirow{2}{*}{,69 } & \multirow{2}{*}{227} & \multirow{2}{*}{,49 } \\
\hline & Evli & 130 & 3,39 &, 76 & & & \\
\hline \multirow{2}{*}{$\begin{array}{l}\text { Örgütsel Değişime } \\
\text { İlişkin Tutum } \\
\text { Ölçeği }\end{array}$} & Bekâr & 99 & 3,49 & ,91 & \multirow[b]{2}{*}{, 76} & \multirow[b]{2}{*}{227} & \multirow[b]{2}{*}{,44 } \\
\hline & Evli & 130 & 3,41 &, 72 & & & \\
\hline
\end{tabular}

Tablo 3 incelendiğinde BİLSEM öğretmenlerinin örgütsel değişime ilişkin tutum düzeylerinin medeni durum faktörüne göre anlamlı bir farklılık gösterip göstermediğinin belirlenmesi amacıyla bağımsız t-testi yapılmış olup BİLSEM öğretmenlerinin tüm ölçekteki değişime ilişkin tutum düzeylerinin medeni durumlarına göre anlamlı şekilde farklılık göstermediği görülmektedir $[\mathrm{t}(227)=, 76 ; \mathrm{p}>$,05]. Tablo 3 incelendiğinde değişme ihtiyacının belirlenmesi alt boyutunda öğretmenlerin medeni durumlarına göre anlamlı farklılık olduğu görülmektedir. Buna göre bekâr öğretmenlerin değişme ihtiyacının belirlenmesi tutum düzeyleri $(\bar{X}=3,53)$ evli öğretmenlere $(\bar{X}=3,32)$ göre anlamlı şekilde daha yüksek bulunmuştur.

\subsection{BİLSEM Öğretmenlerinin Mezuniyet Durumlarına Göre Örgütsel Değişmeye İlişkin Tutum Düzeyleri \\ BİLSEM öğretmenlerinin mezuniyet durumlarına göre örgütsel değişmeye ilişkin tutum düzeyleri tablo 4’te gösterilmiştir.}


International Journal of Scientific and Technological Research

ISSN 2422-8702 (Online), DOI: 10.7176/JSTR/6-06-09

Special Issue of Educational Sciences, Vol.6, No.6, 2020

Tablo 4. BİLSEM Öğretmenlerinin Örgütsel Değişime İlişkin Tutum Düzeylerinin Mezuniyet Durum Değişkenine Göre t-Testi Sonuçları

\begin{tabular}{|c|c|c|c|c|c|c|c|}
\hline Değişkenler & Mezuniyet Durumu & $\mathrm{N}$ & $\mathrm{X}$ & Ss & $\mathrm{t}$ & $\mathrm{Sd}$ & $\mathrm{p}$ \\
\hline \multirow{2}{*}{$\begin{array}{l}\text { Değişme İhtiyacının } \\
\text { Belirlenmesi }\end{array}$} & Lisans & 142 & 3,36 &, 85 & \multirow{2}{*}{$-1,03$} & \multirow{2}{*}{227} & \multirow{2}{*}{0,30} \\
\hline & Yüksek Lisans & 87 & 3,48 & ,86 & & & \\
\hline \multirow{2}{*}{$\begin{array}{l}\text { Değişmenin } \\
\text { Planlanması }\end{array}$} & Lisans & 142 & 3,43 & ,81 & \multirow{2}{*}{,- 51} & \multirow{2}{*}{227} & \multirow{2}{*}{0,61} \\
\hline & Yüksek Lisans & 87 & 3,49 & 1,06 & & & \\
\hline \multirow{2}{*}{$\begin{array}{l}\text { Değişmenin } \\
\text { Uygulanması }\end{array}$} & Lisans & 142 & 3,45 & ,91 & \multirow{2}{*}{,- 67} & \multirow{2}{*}{227} & \multirow{2}{*}{0,50} \\
\hline & Yüksek Lisans & 87 & 3,53 & ,80 & & & \\
\hline \multirow{2}{*}{$\begin{array}{l}\text { Değişmenin } \\
\text { Değerlendirilmesi }\end{array}$} & Lisans & 142 & 3,40 & ,83 & \multirow{2}{*}{,- 51} & \multirow{2}{*}{227} & \multirow{2}{*}{0,60} \\
\hline & Yüksek Lisans & 87 & 3,46 &, 77 & & & \\
\hline \multirow[t]{2}{*}{ Değişimin Felsefesi } & Lisans & 142 & 3,41 &, 84 & \multirow{2}{*}{-36} & \multirow{2}{*}{227} & \multirow{2}{*}{0,71} \\
\hline & Yüksek Lisans & 87 & 3,45 &, 82 & & & \\
\hline \multirow{2}{*}{$\begin{array}{l}\text { Örgütsel Değişime İlişkin } \\
\text { Tutum Ölçeği }\end{array}$} & Lisans & 142 & 3,42 &, 80 & \multirow{2}{*}{,- 58} & \multirow{2}{*}{227} & \multirow{2}{*}{0,56} \\
\hline & Yüksek Lisans & 87 & 3,48 & ,82 & & & \\
\hline
\end{tabular}

Tablo 4 incelendiğinde BİLSEM öğretmenlerinin örgütsel değişime ilişkin tutum düzeylerinin mezuniyet düzeylerine göre anlamlı bir farklılık gösterip göstermediğinin belirlenmesi amacıyla bağımsız t-testi yapılmış olup BİLSEM öğretmenlerinin tüm ölçekteki değişime ilişkin tutum düzeylerinin öğretmenlerin mezuniyet düzeylerine göre anlamlı şekilde farklılık göstermediği görülmektedir $[\mathrm{t}(227)=-, 58 ; \mathrm{p}>0,05]$.

\subsection{BİLSEM Öğretmenlerinin Çalışma Durumlarına Göre Örgütsel Değişmeye İlişkin Tutum Düzeyleri}

BİLSEM öğretmenlerinin çalışma durumlarına göre örgütsel değişmeye ilişkin tutum düzeyleri tablo 5 'te gösterilmiştir.

Tablo 5. BİLSEM Öğretmenlerinin Örgütsel Değişime İlişkin Tutum Düzeylerinin Çalışma Durumu Değişkenine Göre t-Testi Sonuçları

\begin{tabular}{|c|c|c|c|c|c|c|c|}
\hline Değişkenler & $\begin{array}{l}\text { Çalışma } \\
\text { Durumu }\end{array}$ & $\mathrm{N}$ & $X$ & Ss & $\mathrm{t}$ & $\mathrm{Sd}$ & $\mathrm{p}$ \\
\hline \multirow{2}{*}{$\begin{array}{l}\text { Değişme } \\
\text { İhtiyacının } \\
\text { Belirlenmesi }\end{array}$} & Görevlendirme & 124 & 3,32 &, 88 & \multirow[t]{2}{*}{$-1,80$} & \multirow[t]{2}{*}{227} & \multirow[t]{2}{*}{,07 } \\
\hline & Kadrolu & 105 & 3,52 &, 80 & & & \\
\hline \multirow{2}{*}{$\begin{array}{l}\text { Değişmenin } \\
\text { Planlanması }\end{array}$} & Görevlendirme & 124 & 3,39 & 1,07 & \multirow[t]{2}{*}{$-1,24$} & \multirow[t]{2}{*}{227} & \multirow[t]{2}{*}{, 21} \\
\hline & Kadrolu & 105 & 3,54 &, 65 & & & \\
\hline \multirow{2}{*}{$\begin{array}{l}\text { Değişmenin } \\
\text { Uygulanması }\end{array}$} & Görevlendirme & 124 & 3,33 & ,93 & \multirow[t]{2}{*}{$-2,93$} & \multirow[t]{2}{*}{227} & \multirow[t]{2}{*}{, $00 *$} \\
\hline & Kadrolu & 105 & 3,66 & ,77 & & & \\
\hline \multirow{2}{*}{$\begin{array}{l}\text { Değişmenin } \\
\text { Değerlendirilmesi }\end{array}$} & Görevlendirme & 124 & 3,24 & 85 & \multirow[t]{2}{*}{$-3,84$} & \multirow[t]{2}{*}{227} & \multirow[t]{2}{*}{, $00 *$} \\
\hline & Kadrolu & 105 & 3,64 &, 70 & & & \\
\hline \multirow{2}{*}{$\begin{array}{l}\text { Değişimin } \\
\text { Felsefesi }\end{array}$} & Görevlendirme & 124 & 3,32 &, 87 & \multirow[t]{2}{*}{$-2,12$} & \multirow[t]{2}{*}{227} & \multirow[t]{2}{*}{, $03 *$} \\
\hline & Kadrolu & 105 & 3,55 & ,77 & & & \\
\hline \multirow{2}{*}{$\begin{array}{l}\text { Örgütsel Değişime İlişkin } \\
\text { Tutum Ölçeği }\end{array}$} & Görevlendirme & 124 & 3,33 & ,88 & \multirow[t]{2}{*}{$-2,29$} & \multirow[t]{2}{*}{227} & \multirow[t]{2}{*}{, $02 *$} \\
\hline & Kadrolu & 105 & 3,58 & ,69 & & & \\
\hline
\end{tabular}

$* \mathrm{p}<, 05$

$\mathbf{1 2 2} \mid \mathrm{P}$ a g e

www.iiste.org 
International Journal of Scientific and Technological Research

ISSN 2422-8702 (Online), DOI: 10.7176/JSTR/6-06-09

Special Issue of Educational Sciences, Vol.6, No.6, 2020

Tablo 5 incelendiğinde BİLSEM öğretmenlerinin örgütsel değişime ilişkin tutum düzeylerinin çalışma durumlarına göre anlamlı bir farklılık gösterip göstermediğini belirlemek amacıyla bağımsız t-testi yapılmış olup BİLSEM öğretmenlerinin tüm ölçekteki değişime ilişkin tutum düzeyleri öğretmenlerin çalışma durumlarına göre anlamlı şekilde farklılık gösterdiği görülmektedir $[\mathrm{t}(227)=-2,29 ; \mathrm{p}<, 05]$. Kadrolu öğretmenlerin örgütsel değişime ilişkin tutum düzeyleri $(\overline{\mathrm{X}}=3,58)$ görevlendirme olarak çalışan öğretmenlere $(\bar{X}=3,33)$ göre anlamlı şekilde daha yüksek bulunmuştur. Alt boyutlardan değişmenin uygulanması, değişmenin değerlendirilmesi ve değişimin felsefesi alt boyutlarında öğretmenlerin tutum düzeyleri çalışma durumlarına göre kadrolu öğretmenler yönünde anlamlı şekilde farklılık gösterdiği görülmektedir.

\subsection{BİLSEM Öğretmenlerinin Yaşlarına Göre Örgütsel Değişmeye İlişkin Tutum Düzeyleri}

BİLSEM öğretmenlerinin yaş durumlarına göre örgütsel değişmeye ilişkin tutum düzeyleri tablo 6'da gösterilmiştir.

Tablo 6. BİLSEM Öğretmenlerinin Örgütsel Değişime İlişkin Tutum Düzeylerinin Yaş Değişkenine Göre Anova Sonuçları

\begin{tabular}{|c|c|c|c|c|c|c|c|c|c|c|c|}
\hline \multicolumn{5}{|c|}{ F, $X$ ve Ss Değerleri } & \multicolumn{6}{|c|}{ Anova Sonuçları } & \multirow[b]{2}{*}{$\begin{array}{c}\text { Anlamlı } \\
\text { Fark }\end{array}$} \\
\hline \multirow{5}{*}{ 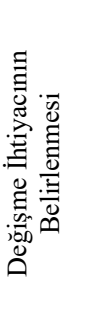 } & Yaş & $\mathrm{N}$ & $\mathrm{X}$ & Ss & Var. K. & K.T. & $\mathrm{Sd}$. & K.O & $\mathrm{F}$ & $\mathrm{p}$ & \\
\hline & (1)21-30 yaş & 81 & 3,30 &, 86 & \multirow[t]{2}{*}{ G..A. } & \multirow[t]{2}{*}{16,200} & \multirow[t]{2}{*}{2} & \multirow[t]{2}{*}{8,10} & \multirow[t]{4}{*}{12,10} & \multirow[t]{4}{*}{, $00^{*}$} & \multirow{4}{*}{$\begin{array}{l}1-3 \\
2-3\end{array}$} \\
\hline & (2)31-40 yaş & 74 & 3,16 &, 87 & & & & & & & \\
\hline & (3)41 ve üstü yaş & 74 & 3,79 &, 69 & G..I. & 151,27 & 226 & ,66 & & & \\
\hline & Toplam & 229 & 3,41 &, 85 & Top. & 167,47 & 228 & & & & \\
\hline \multirow{5}{*}{ 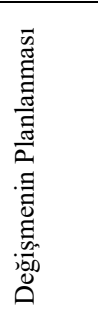 } & Yaş & $\mathrm{N}$ & $\mathrm{X}$ & Ss & Var. K. & K.T. & $\mathrm{Sd}$. & K.O & $\mathrm{F}$ & $\mathrm{p}$ & $\begin{array}{c}\text { Anlamlı } \\
\text { Fark }\end{array}$ \\
\hline & (1)21-30 yaş & 81 & 3,33 &, 63 & \multirow[t]{2}{*}{ G..A. } & \multirow[t]{2}{*}{26,86} & \multirow[t]{2}{*}{2} & \multirow[t]{2}{*}{13,43} & \multirow[t]{4}{*}{18,86} & \multirow[t]{4}{*}{, $00^{*}$} & \multirow{4}{*}{$\begin{array}{l}1-3 \\
2-3\end{array}$} \\
\hline & (2)31-40 yaş & 74 & 3,11 &, 85 & & & & & & & \\
\hline & (3)41 ve üstü yaş & 74 & 3,93 & 1,01 & G..I. & 160,94 & 226 &, 71 & & & \\
\hline & Toplam & 229 & 3,46 &, 90 & Top. & 187,80 & 228 & & & & \\
\hline \multirow{5}{*}{ 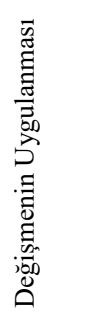 } & Yaş & $\mathrm{N}$ & X & Ss & Var. K. & K.T. & Sd. & K.O & $\mathrm{F}$ & $\mathrm{p}$ & $\begin{array}{c}\text { Anlamlı } \\
\text { Fark }\end{array}$ \\
\hline & (1)21-30 yaş & 81 & 3,44 &, 80 & \multirow[t]{2}{*}{ G..A. } & \multirow[t]{2}{*}{15,53} & \multirow[t]{2}{*}{2} & \multirow[t]{2}{*}{7,76} & \multirow[t]{4}{*}{10,96} & \multirow[t]{4}{*}{, $00^{*}$} & \multirow{4}{*}{$\begin{array}{l}1-3 \\
2-3\end{array}$} \\
\hline & (2)31-40 yaş & 74 & 3,18 & 1,02 & & & & & & & \\
\hline & (3)41 ve üstü yaş & 74 & 3,83 &, 65 & G..I. & 160,10 & 226 &, 70 & & & \\
\hline & Toplam & 229 & 3,48 &, 87 & Top. & 175,63 & 228 & & & & \\
\hline \multirow{5}{*}{ 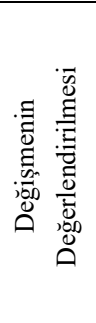 } & Yaş & $\mathrm{N}$ & $X$ & Ss & Var. K. & K.T. & Sd. & K.O & $\mathrm{F}$ & $\mathrm{p}$ & $\begin{array}{c}\text { Anlamlı } \\
\text { Fark }\end{array}$ \\
\hline & (1)21-30 yaş & 81 & 3,43 &, 69 & \multirow[t]{2}{*}{ G..A. } & \multirow[t]{2}{*}{15,49} & \multirow[t]{2}{*}{2} & 7,749 & 12,93 &, $00 *$ & $1-2$ \\
\hline & (2)31-40 yaş & 74 & 3,09 &, 97 & & & & & & & $1-3$ \\
\hline & (3)41 ve üstü yaş & 74 & 3,74 &, 62 & G..İ. & 135,44 & 226 & ,599 & & & $2-3$ \\
\hline & Toplam & 229 & 3,42 &, 81 & Top. & 150,93 & 228 & & & & \\
\hline & Yaş & $\mathrm{N}$ & $\mathrm{X}$ & Ss & Var. K. & K.T. & $\mathrm{Sd}$. & K.O & $\mathrm{F}$ & $\mathrm{p}$ & $\begin{array}{c}\text { Anlamlı } \\
\text { Fark }\end{array}$ \\
\hline 活 & (1)21-30 yaş & 81 & 3,45 &, 67 & G..A. & 20,43 & 2 & 10,219 & 16,68 &, $00 *$ & $1-2$ \\
\hline & (2)31-40 yaş & 74 & 3,04 &, 94 & & & & & & & $1-3$ \\
\hline
\end{tabular}

$\mathbf{1 2 3} \mid \mathrm{P}$ a g e

www.iiste.org 
International Journal of Scientific and Technological Research

ISSN 2422-8702 (Online), DOI: 10.7176/JSTR/6-06-09

Special Issue of Educational Sciences, Vol.6, No.6, 2020

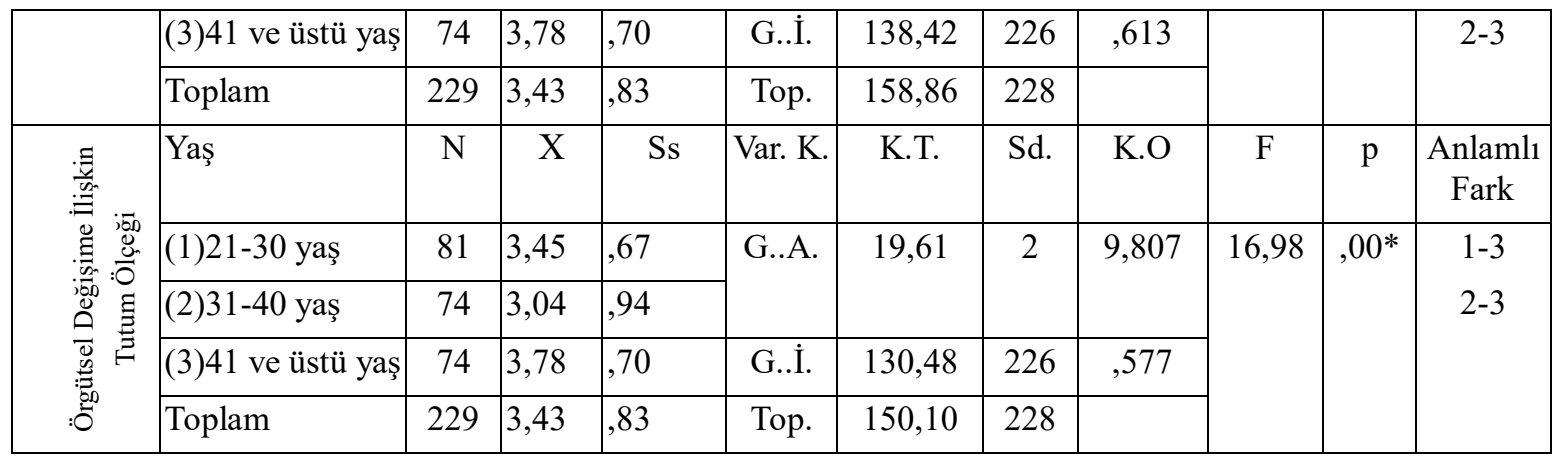

$* \mathrm{p}<, 05$

Tablo 6 incelendiğinde BİLSEM öğretmenlerinin örgütsel değişime ilişkin tutum düzeylerinin yaşlarına göre anlamlı bir farklılık gösterip göstermediğini belirlemek amacıyla yapılan tek yönlü varyans analizi (ANOVA) testi sonucunda öğretmenleri örgütsel değişim tutumlarının yaşlarına göre anlamlı şekilde farklılık gösterdiği bulunmuştur [F $(2 ; 226)=16,98 ; \mathrm{p}<, 05]$. Farkın hangi gruplar arasında olduğunu bulmak amacıyla TUKEY HSD testi yapılmış olup 41 ve üstü yaş grubundaki öğretmenler ile 21-30 yaş ve 21-40 yaş arasında 41 yaş ve üstü öğretmenler lehine anlamlı bir fark olduğu görülmüştür.

\subsection{BíLSEM Öğretmenlerinin Örgütsel Muhalefet Davranış Düzeyleri}

Öğretmenlerin örgütsel muhalefet davranış düzeyleri ortalama puanları açısından incelenmesi Tablo 7'de gösterilmiştir.

Tablo 7. Örgütsel Muhalefet Ölçeği ve Ölçeğin Alt Boyutlarına İle İlgili Analiz Sonuçları

\begin{tabular}{|l|c|c|c|c|}
\hline Değişkenler & $\mathrm{N}$ & $\mathrm{X}$ & $\mathrm{Ss}$ & Madde Sayıs1 \\
\hline Dikey Muhalefet & 229 & 3,64 &, 57 & 8 \\
\hline Yatay Muhalefet & 229 & 3,41 &, 53 & 7 \\
\hline Örgütsel Muhalefet Ölçeği & 229 & 3,52 &, 49 & 15 \\
\hline
\end{tabular}

Tablo 7 incelendiğinde BİLSEM öğretmenlerinin örgütsel muhalefet davranış düzeylerinin aritmetik ortalamalarının $\bar{X}=3,52$ ve standart sapmasının $\mathrm{Ss}=, 46$ olduğu görülmektedir. Örneklem grubunun dikey muhalefet alt boyutunun aritmetik ortalamasının $\bar{X}=3,64$ olduğu, yatay muhalefet alt boyutunun aritmetik ortalamasının $\bar{X}=3,41$ olduğu gözlenmektedir.

\subsection{BíLSEM Öğretmenlerinin Cinsiyetlerine Göre Örgütsel Muhalefet Davranış Düzeyleri}

BILLSEM öğretmenlerinin cinsiyetlerine göre örgütsel muhalefet davranış düzeyleri tablo 8'de gösterilmiştir.

Tablo 8. BİLSEM Öğretmenlerinin Örgütsel Muhalefet Davranış Düzeylerinin Cinsiyet Değişkenine Göre t-Testi Sonuçları

\begin{tabular}{|c|c|c|c|c|c|c|c|}
\hline Değişkenler & Cinsiyet & $\mathrm{N}$ & $\mathrm{X}$ & Ss & $\mathrm{t}$ & $\mathrm{Sd}$ & $\mathrm{p}$ \\
\hline \multirow[t]{2}{*}{ Dikey Muhalefet } & Kadın & 94 & 3,43 & ,69 & \multirow{2}{*}{$-4,88$} & \multirow{2}{*}{227} & \multirow{2}{*}{, $000^{*}$} \\
\hline & Erkek & 135 & 3,79 & 4,41 & & & \\
\hline \multirow[t]{2}{*}{ Yatay Muhalefet } & Kadın & 94 & 3,19 &, 52 & \multirow{2}{*}{$-5,57$} & \multirow{2}{*}{227} & \multirow{2}{*}{, $000^{*}$} \\
\hline & Erkek & 135 & 3,57 &, 49 & & & \\
\hline \multirow{2}{*}{$\begin{array}{l}\text { Örgütsel } \\
\text { Muhalefet Ölçeği }\end{array}$} & Kadın & 94 & 3,30 &, 54 & \multirow{2}{*}{$-5,95$} & \multirow{2}{*}{227} & \multirow{2}{*}{, $000^{*}$} \\
\hline & Erkek & 135 & 3,67 &, 39 & & & \\
\hline
\end{tabular}

${ }^{*} \mathrm{p}<, 05$

124|P a g e

www.iiste.org 
Tablo 8 incelendiğinde BİLSEM öğretmenlerinin örgütsel muhalefet davranış düzeylerinin cinsiyet faktörüne göre anlamlı bir farklılık gösterip göstermediğini belirlemek amacıyla bağımsız t-testi yapılmış olup BİLSEM öğretmenlerinin tüm ölçekteki muhalefet davranış düzeyleri öğretmenlerin cinsiyetlerine göre anlamlı şekilde farklılık gösterdiği görülmektedir $[\mathrm{t}(227)=-5,95 ; \mathrm{p}<, 05]$. Erkek öğretmenlerin örgütsel muhalefet davranış düzeyleri $(\overline{\mathrm{X}}=3,67)$, kadın öğretmenlere göre $(\overline{\mathrm{X}}=3,30)$, anlamlı şekilde daha yüksek bulunmuştur. Aynı şekilde hem dikey muhalefet hem de yatay muhalefet boyutlarında erkek öğretmenlerin davranış düzeyleri kadın öğretmenlere göre anlamlı şekilde daha yüksek olduğu bulunmuştur.

\subsection{BİLSEM Öğretmenlerinin Medeni Durumlarına Göre Örgütsel Muhalefet Davranış Düzeyleri} BİLSEM öğretmenlerinin medeni durumlarına göre örgütsel muhalefet davranış düzeyleri tablo 9'da gösterilmiştir.

Tablo 9. BİLSEM Öğretmenlerinin Örgütsel Muhalefet Davranış Düzeylerinin Medeni Durum Değişkenine Göre t-Testi Sonuçları

\begin{tabular}{|c|c|c|c|c|c|c|c|}
\hline Değişkenler & $\begin{array}{l}\text { Medeni } \\
\text { Durum }\end{array}$ & $\mathrm{N}$ & $\mathrm{X}$ & Ss & $\mathrm{t}$ & $\mathrm{Sd}$ & $\mathrm{p}$ \\
\hline \multirow[t]{2}{*}{ Dikey Muhalefet } & Bekâr & 99 & 3,50 & ,54 & \multirow{2}{*}{$-3,36$} & \multirow{2}{*}{227} & \multirow{2}{*}{, $01 *$} \\
\hline & Evli & 130 & 3,75 & ,57 & & & \\
\hline \multirow[t]{2}{*}{ Yatay Muhalefet } & Bekâr & 99 & 3,41 & ,52 & \multirow{2}{*}{, 11} & \multirow{2}{*}{227} & \multirow{2}{*}{,92 } \\
\hline & Evli & 130 & 3,41 &, 55 & & & \\
\hline \multirow[t]{2}{*}{ Örgütsel Muhalefet Ölçeği } & Bekâr & 99 & 3,45 & ,49 & \multirow{2}{*}{$-1,71$} & \multirow{2}{*}{227} & \multirow{2}{*}{, 09} \\
\hline & Evli & 130 & 3,57 & ,49 & & & \\
\hline
\end{tabular}

$\mathrm{p}<, 05$

Tablo 9 incelendiğinde BİLSEM öğretmenlerinin örgütsel muhalefet davranış düzeylerinin medeni durum faktörüne göre anlamlı bir farklılık gösterip göstermediğinin belirlenmesi amacıyla bağımsız t-testi yapılmış olup BİLSEM öğretmenlerinin tüm ölçekteki değişime ilişkin tutum düzeylerinin medeni durumlarına göre anlamlı şekilde farklılık göstermediği görülmektedir $[\mathrm{t}(227)=-1,71 ; \mathrm{p}>, 05]$. Sadece dikey muhalefet alt boyutunda öğretmenlerin medeni durumlarına göre anlamlı farklılık olduğu görülmektedir. Buna göre evli öğretmenlerin dikey muhalefet düzeyleri $(\bar{X}=3,75)$ evli öğretmenlere $(\bar{X}=3,50)$ göre anlamlı şekilde daha yüksek bulunmuştur.

\subsection{BİLSEM Öğretmenlerinin Mezuniyet Durumlarına Göre Örgütsel Muhalefet Davranış} Düzeyleri

BİLSEM öğretmenlerinin mezuniyet durumlarına göre örgütsel muhalefet davranış düzeyleri tablo 10 'da gösterilmiştir.

Tablo 10. BİLSEM Öğretmenlerinin Örgütsel Muhalefet Davranış Düzeylerinin Mezuniyet Durum Değişkenine Göre t-Testi Sonuçları

\begin{tabular}{|c|c|c|c|c|c|c|c|}
\hline Değişkenler & $\begin{array}{c}\text { Mezuniyet } \\
\text { Durumu }\end{array}$ & $\mathbf{N}$ & $\mathrm{X}$ & Ss & $\mathbf{t}$ & Sd & $\mathbf{p}$ \\
\hline \multirow[t]{2}{*}{ Dikey Muhalefet } & Lisans & 142 & 3,69 & ,56 & \multirow[b]{2}{*}{1,69} & \multirow[b]{2}{*}{227} & \multirow[b]{2}{*}{09} \\
\hline & $\begin{array}{l}\text { Yüksek } \\
\text { Lisans }\end{array}$ & 87 & 3,56 & ,59 & & & \\
\hline \multirow[t]{2}{*}{ Yatay Muhalefet } & Lisans & 142 & 3,37 &, 56 & \multirow[b]{2}{*}{$-1,47$} & \multirow[b]{2}{*}{227} & \multirow[b]{2}{*}{, 14 } \\
\hline & $\begin{array}{l}\text { Yüksek } \\
\text { Lisans }\end{array}$ & 87 & 3,48 & ,49 & & & \\
\hline \multirow{2}{*}{$\begin{array}{l}\text { Örgütsel } \\
\text { Ölçeği }\end{array}$} & Lisans & 142 & 3,525 &, 50 & \multirow[b]{2}{*}{, 06} & \multirow[b]{2}{*}{227} & \multirow[b]{2}{*}{,95 } \\
\hline & $\begin{array}{l}\text { Yüksek } \\
\text { Lisans }\end{array}$ & 87 & 3,52 & 48 & & & \\
\hline
\end{tabular}


Tablo 10 incelendiğinde BİLSEM öğretmenlerinin örgütsel muhalefet davranış düzeylerinin mezuniyet düzeylerine göre anlamlı bir farklılık gösterip göstermediğinin belirlenmesi amacıyla bağımsız t-testi yapılmış olup BİLSEM öğretmenlerinin tüm ölçekteki örgütsel muhalefet düzeylerinin öğretmenlerin mezuniyet düzeylerine göre anlamlı şekilde farklılık göstermediği görülmektedir $[\mathrm{t}(227)=, 06 ; \mathrm{p}>0,05]$.

\subsection{BİLSEM Öğretmenlerinin Çalışma Durumlarına Göre Örgütsel Muhalefet Davranış Düzeyleri} BİLSEM öğretmenlerinin çalışma durumlarına göre örgütsel muhalefet davranış düzeyleri tablo 11 'de gösterilmiştir.

Tablo 11. BİLSEM Öğretmenlerinin Örgütsel Muhalefet Davranış Düzeylerinin Çalışma Durumu Değişkenine Göre t-Testi Sonuçları

\begin{tabular}{|c|c|c|c|c|c|c|c|}
\hline Değişkenler & $\begin{array}{l}\text { Çalışma } \\
\text { Durumu }\end{array}$ & $\mathrm{N}$ & $\mathrm{X}$ & Ss & $\mathrm{t}$ & $\mathrm{Sd}$ & $\mathrm{p}$ \\
\hline \multirow[t]{2}{*}{ Dikey Muhalefet } & Görevlendirme & 124 & 3,51 &, 58 & \multirow{2}{*}{$-3,96$} & \multirow{2}{*}{227} & \multirow{2}{*}{, $00 *$} \\
\hline & Kadrolu & 105 & 3,80 & ,53 & & & \\
\hline \multirow[t]{2}{*}{ Yatay Muhalefet } & Görevlendirme & 124 & 3,37 & ,58 & \multirow{2}{*}{$-1,16$} & \multirow{2}{*}{227} & \multirow{2}{*}{,24 } \\
\hline & Kadrolu & 105 & 3,45 &, 47 & & & \\
\hline \multirow{2}{*}{$\begin{array}{ll}\text { Örgütsel } & \text { Muhalefet } \\
\text { Ölçeği } & \end{array}$} & Görevlendirme & 124 & 3,44 &, 51 & \multirow{2}{*}{$-2,79$} & \multirow{2}{*}{227} & \multirow{2}{*}{, $00 *$} \\
\hline & Kadrolu & 105 & 3,62 & 45 & & & \\
\hline
\end{tabular}

$* \mathrm{p}<, 05$

Tablo 11 incelendiğinde BİLSEM öğretmenlerinin örgütsel muhalefet davranış düzeylerinin çalışma durumlarına göre anlamlı bir farklılık gösterip göstermediğini belirlemek amacıyla bağımsız t testi yapılmış olup BİLSEM öğretmenlerinin tüm ölçekteki örgütsel muhalefet düzeyleri öğretmenlerin çalışma durumlarına göre anlamlı şekilde farklılık gösterdiği görülmektedir $[\mathrm{t}(227)=-2,79 ; \mathrm{p}<, 05]$. Kadrolu öğretmenlerin örgütsel muhalefet düzeyleri $(\overline{\mathrm{X}}=3,62)$ görevlendirme olarak çalışan öğretmenlere $(\overline{\mathrm{X}}=3,44)$ göre anlamlı şekilde daha yüksek bulunmuştur. Öğretmenlerin çalışma durumuna göre dikey muhalefet düzeylerinde anlamlı fark bulunurken yatay muhalefet boyutunda anlamlı düzeyde fark bulunamamıştır.

\subsection{BİLSEM Öğretmenlerinin Yaşlarına Göre Örgütsel Muhalefet Davranış Düzeyleri}

BİLSEM öğretmenlerinin yaş durumlarına göre örgütsel muhalefet davranış düzeyleri tablo 12 'de gösterilmiştir.

Tablo 12. BİLSEM Öğretmenlerinin Örgütsel Muhalefet Davranış Düzeylerinin Yaş Değişkenine Göre Anova Sonuçları

\begin{tabular}{|c|c|c|c|c|c|c|c|c|c|c|c|}
\hline \multicolumn{5}{|c|}{$\mathrm{F}, \overline{\mathbf{X}}$ ve Ss Değerleri } & \multicolumn{6}{|c|}{ Anova Sonuçları } & \\
\hline \multirow{5}{*}{ 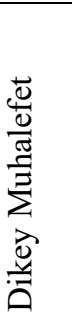 } & Yaş & $\mathrm{N}$ & $\mathrm{X}$ & Ss & Var. K. & K.T. & $\mathrm{Sd}$. & K.O & $\mathrm{F}$ & $\mathrm{p}$ & $\begin{array}{c}\text { Anlamlı } \\
\text { Fark }\end{array}$ \\
\hline & (1)21-30 yaş & 81 & 3,68 & 3,33 & \multirow[t]{2}{*}{ G..A. } & \multirow[t]{2}{*}{3,484} & \multirow[t]{2}{*}{2} & \multirow[t]{2}{*}{1,74} & \multirow{4}{*}{5,43} & \multirow{4}{*}{, $00^{*}$} & \multirow{4}{*}{$2-3$} \\
\hline & (2)31-40 yaş & 74 & 3,48 & 3,21 & & & & & & & \\
\hline & (3)41 ve üstü yaş & 74 & 3,78 & 3,70 & G..I. & 72,411 & 226 & ,32 & & & \\
\hline & Toplam & 229 & 3,64 & 3,41 & Toplam & 75,895 & 228 & & & & \\
\hline 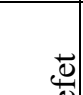 & Yaş & $\mathrm{N}$ & $\mathrm{X}$ & Ss & Var. K. & K.T. & $\mathrm{Sd}$. & K.O & $\mathrm{F}$ & $\mathrm{p}$ & $\begin{array}{c}\text { Anlamlı } \\
\text { Fark }\end{array}$ \\
\hline$\gtrsim \stackrel{\Xi}{\Xi}$ & (1)21-30 yaş & 81 & 3,33 & ,35 & G.Aras1 & 9,949 & 2 & 4,974 & 19,8 & & $1-3$ \\
\hline$\approx \Sigma$ & (2)31-40 yaş & 74 & 3,21 & ,60 & & & & & 9 & , & $2-3$ \\
\hline
\end{tabular}

$\mathbf{1 2 6} \mid \mathrm{P}$ a g e

www.iiste.org 
International Journal of Scientific and Technological Research

ISSN 2422-8702 (Online), DOI: 10.7176/JSTR/6-06-09

Special Issue of Educational Sciences, Vol.6, No.6, 2020

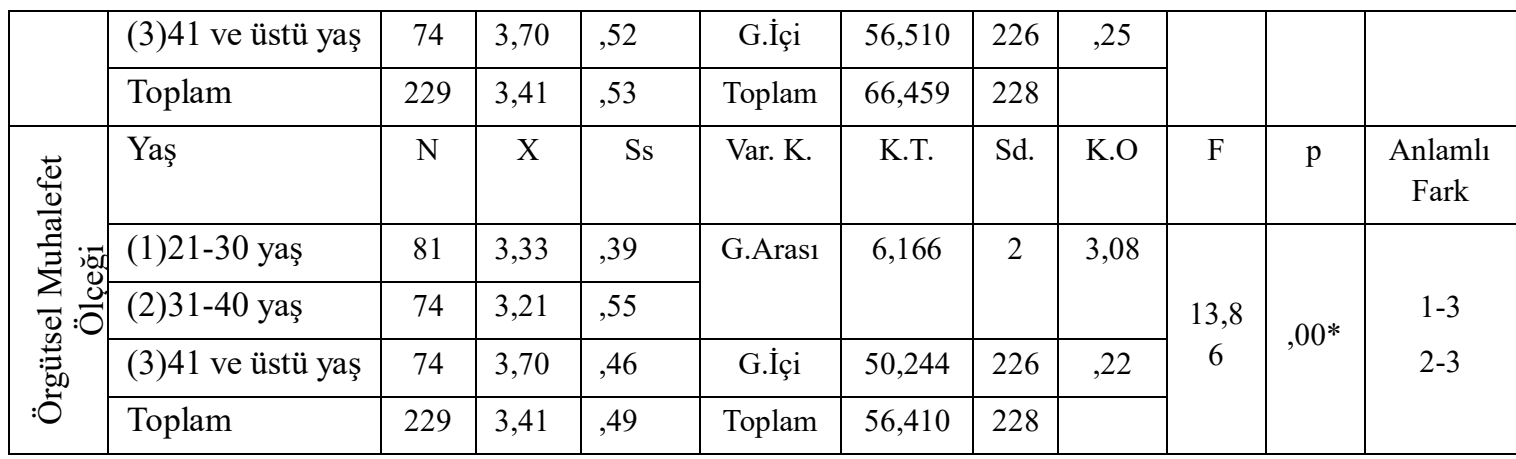

$* \mathrm{p}<, 05$

Tablo 12 incelendiğinde BİLSEM öğretmenlerinin örgütsel muhalefet davranış düzeylerinin yaşlarına göre anlamlı bir farklılık gösterip göstermediğini belirlemek amacıyla yapılan tek yönlü varyans analizi (ANOVA) testi sonucunda öğretmenleri örgütsel muhalefet davranış düzeylerinin yaşlarına göre anlamlı şekilde farklılık gösterdiği bulunmuştur [F $(2 ; 226)=13,86 ; \mathrm{p}<, 05]$. Farkın hangi gruplar arasında olduğunu bulmak amacıyla TUKEY HSD testi yapılmış olup 41 ve üstü yaş grubundaki öğretmenler ile 21-30 yaş ve 21-40 yaş arasında 41 yaş ve üstü öğretmenler lehine anlamlı bir fark olduğu görülmüştür. Aynı şekilde dikey muhalefet boyutunda 41 ve üstü yaş grubundaki öğretmenler ile 21-30 yaş öğretmenler arasında 41 ve üstü yaş grubundaki öğretmenlerin lehine, yatay muhalefet boyutunda ise 41 ve üstü yaş grubundaki öğretmenler ile 21-30 yaş ve 21-40 yaş arasında 41 yaş ve üstü öğretmenler lehine anlamlı bir fark olduğu görülmüştür.

\subsection{BİLSEM Öğretmenlerinin Örgütsel Değişim ve Örgütsel Muhalefet Algıları Arasındaki İlişkinin Analizi \\ BİLSEM öğretmenlerinin örgütsel değişim ve örgütsel muhalefet algıları arasındaki ilişki tablo 13 'te gösterilmiştir.}

Tablo 13. BİLSEM Öğretmenlerinin Örgütsel Değişim ve Örgütsel Muhalefet Algıları Arasındaki İlişkiye Ait Korelasyon Analizi Sonuçları

\begin{tabular}{|l|l|c|c|c|c|}
\hline & & 1 & 2 & 3 & 4 \\
\hline $\begin{array}{l}\text { 1- Örgütsel Değişime İlişkin Tutum } \\
\text { Ölçeği (Tüm Ölçek) }\end{array}$ & $\mathrm{r}$ & 1 &, $672^{* *}$ &, $734^{* *}$ &, $789^{* *}$ \\
\hline 2-Dikey Muhalefet & $\mathrm{r}$ &, $672^{* *}$ & 1 &, $593^{* *}$ &, $885^{* *}$ \\
\hline 3-Yatay Muhalefet & $\mathrm{r}$ &, $734^{* *}$ &, $593^{* *}$ & 1 &, $900^{* *}$ \\
\hline $\begin{array}{l}\text { 4-Örgütsel Muhalefet } \\
\text { Ölçeği (Tüm Ölçek) }\end{array}$ & $\mathrm{r}$ &, $789^{* *}$ &, $885^{* *}$ &, $900^{* *}$ & 1 \\
\hline
\end{tabular}

** $\mathrm{p}<.01$ düzeyinde anlaml 1

Tablo 13 incelendiğinde, BİLSEM'de çalışan öğretmenlerin örgütsel değişim ile örgütsel muhalefet algıları arasında yüksek düzeyde pozitif yönde ve anlamlı bir ilişki olduğu görülmektedir $(\mathrm{r}=, 789$; $\mathrm{p}<, 01$ ). Aynı şekilde örgütsel değişim ile dikey muhalefet algısı arasında orta düzeyde pozitif ve anlamlı bir ilişki olduğu $(r=, 672 ; \mathrm{p}<, 01)$; örgütsel değişim ile yatay muhalefet algısı arasında yüksek düzeyde pozitif ve anlamlı bir ilişki olduğu $(r=, 734 ; \mathrm{p}<, 01)$ görülmektedir.

\subsection{BİLSEM Öğretmenlerinin Örgütsel Değişim Algılarının Örgütsel Muhalefet Algıları Üzerindeki Etkisine İlişkin Regresyon Analizi}

BİLSEM öğretmenlerinin örgütsel değişime ilişkin algılarının, örgütsel muhalefet ve onun alt boyutları üzerindeki etkisini araştırmak amacıyla yapılan regresyon analizi sonuçları Tablo 14'te yer almaktadır. 
International Journal of Scientific and Technological Research

ISSN 2422-8702 (Online), DOI: 10.7176/JSTR/6-06-09

Special Issue of Educational Sciences, Vol.6, No.6, 2020

Tablo 14. BİLSEM Öğretmenlerinin Örgütsel Değişim Algılarının Dikey Muhalefet Algıları Üzerindeki Etkisine İlişkin Regresyon Analizi Sonuçları

\begin{tabular}{|l|c|c|c|c|c|}
\hline Değişken & B & Sh & B & T & $p$ \\
\hline Sabit & 2,001 &, 124 & & 16,158 &, 000 \\
\hline Örgütsel Değişin &, 478 &, 035 &, 672 & 13,671 &, 000 \\
\hline $\mathrm{R}=0,672 \quad \mathrm{R}^{2}=0,452$ & & & & & \\
\hline $\mathrm{F}=186,909 \mathrm{p}=.0000$ & & & & & \\
\hline
\end{tabular}

Tablo 14 incelendiğinde öğretmenlerin örgütsel değişim algıları ile dikey muhalefet algıları arasında pozitif yönde ve orta düzeyde bir ilişki bulunduğu görülmektedir $\left(\mathrm{R}=0,672 ; \mathrm{R}^{2}=0.452\right)$. Buna göre, öğretmenlerin örgütsel değişim algıları, dikey muhalefet algılarındaki değişimin \%45'ini açıklamaktadır.

Tablo 15. BİLSEM Öğretmenlerinin Örgütsel Değişim Algılarının Yatay Muhalefet Algıları Üzerindeki Etkisine İlişkin Regresyon Analizi Sonuçları

\begin{tabular}{|l|c|c|c|c|c|}
\hline Değişken & B & Sh & $\beta$ & $T$ & $p$ \\
\hline Sabit & 1,730 &, 106 & & 16,279 &, 000 \\
\hline Örgütsel Değişin &, 488 &, 030 &, 734 & 16,282 &, 000 \\
\hline $\mathrm{R}=0,734 \quad \mathrm{R}^{2}=0,539$ & & & & & \\
\hline $\mathrm{F}=265,109 \mathrm{p}=.0000$ & & & & & \\
\hline
\end{tabular}

Tablo 15, öğretmenlerin örgütsel değişim algıları ile yatay muhalefet algıları arasında pozitif yönde ve orta düzeyde bir ilişkinin varlığına işaret etmektedir $\left(\mathrm{R}=0,734 ; \mathrm{R}^{2}=0,539\right)$. Buna göre, öğretmenlerin örgütsel değişim algıları, yatay muhalefet algılarındaki değişimin \%53’ünü açıklamaktadır.

Tablo 16. BíLSEM Öğretmenlerinin Örgütsel Değişim Algılarının Örgütsel Muhalefet Algıları Üzerindeki Etkisine İlişkin Regresyon Analizi Sonuçları

\begin{tabular}{|l|c|c|c|c|c|}
\hline Değişken & B & Sh & $\beta$ & $\mathrm{T}$ & $\mathrm{p}$ \\
\hline Sabit & 1,856 &, 089 & & 20,944 &, 000 \\
\hline Örgütsel Değişin &, 483 &, 025 &, 789 & 19,325 &, 000 \\
\hline $\mathrm{R}=0,789 \quad \mathrm{R}^{2}=0,622$ & & & & & \\
\hline $\mathrm{F}=373,449 \mathrm{p}=.0000$ & & & & & \\
\hline
\end{tabular}

Tablo 16, öğretmenlerin örgütsel değişim algıları ile örgütsel muhalefet algıları arasında pozitif yönde ve orta düzeyde bir ilişkinin bulunduğunu göstermektedir $\left(\mathrm{R}=0,789 ; \mathrm{R}^{2}=0,622\right)$. Buna göre, öğretmenlerin örgütsel değişim algıları, örgütsel muhalefet algılarındaki değişimin \%62'sini açıklamaktadır.

\section{Tartışma, Sonuç ve Öneriler}

Araştırma sonuçlarına göre BİLSEM öğretmenlerinin örgütsel değişime yönelik algılarının 'katılıyorum" düzeyinde olduğu belirlenmiştir. BİLSEM'lerde görev yapan öğretmenlerin örgütsel değişime ilişkin algılarının "katılıyorum" düzeyinde olmasının birden fazla nedeni olabilir. Bunlar öğretmenlerin değişim doğrultusunda çok daha fazla teşvik edilmemeleri, kurum hakkında kısıtlı bilgiye sahip olmaları ve mevcut ödüllendirme sistemlerinin değişim ile ilişkilendirilmemiş olması olabilir. Alanyazın incelendiğinde Kurşunoğlu ve Tanrı̈ğen (2006) tarafindan yapılan araştırmada da öğretmenlerin örgütsel değişim algıları orta düzeydedir. Akpınar ve Aydın (2007) tarafından gerçekleştirilen çalışmada ise öğretmenlerin örgütsel değişime ilişkin algılarının 'tamamen

$\mathbf{1 2 8} \mid \mathrm{P}$ a g e

www.iiste.org 
katılıyorum" düzeyinde olduğu belirlenmiştir. Araştırma sonuçlarına göre BİLSEM öğretmenlerinin örgütsel değişime yönelik algı düzeylerinin cinsiyet değişkenine göre anlamlı farklılık gösterdiği ve erkek öğretmenlerin kadın meslektaşlarına kıyasla daha yüksek değişim algısına sahip oldukları saptanmıştır. Bunun nedeninin BİLSEM'lerde gerçekleştirilen faaliyetlerde (projeler, il dış1 etkinlikler, geziler, kamplar vb) erkek öğretmenlerin kadın meslektaşlarına göre daha fazla aktif rol alabilmeleri, kararlara doğrudan katılabilmeleri ve BİLSEM yönetimi ile çok daha fazla işbirliği içinde çalışmaları olabilir. Alanyazın incelendiğinde benzer sonuçlar ortaya koyan çalışmalara rastlanmıştır. Doğru ve Uyar (2012), Demirtaş (2012), Cenker ve Macaroğlu Akgül (2011) ile Çağlar (2013) araştırmalarında kadın öğretmenlerin değişimi bir sorun yumağı olarak gördüğü, erkek öğretmenlerin ise değişime daha istekli olduğu yönünde sonuca ulaşmışlardır. Helvacı ve Kıcıroğlu (2010) tarafindan ilköğretim okullarında çalışan öğretmenlerle yapılan araştırmada ise cinsiyet değişkenine göre öğretmenlerin değişime karşı algı düzeylerinde anlamlı bir farklılık oluşmadığı sonucuna ulaşmıştır. Araştırma sonuçlarına göre BİLSEM öğretmenlerinin örgütsel değişime yönelik algı düzeylerinde medeni durum ve öğrenim düzeyi değişkenlerine göre anlamlı düzeyde farklılık bulunmamıştır. Benzer şekilde Levent (2016) ile Kurşunoğlu ve Tanrı̈ŏğen (2006) öğretmenlerin örgütsel değişmeye karşı algılarının öğrenim düzeylerine göre farklılaşmadığı sonucuna ulaşmışlardır. Araştırma sonuçlarına göre BİLSEM öğretmenlerinin çalışma şekillerine göre örgütsel değişime ilişkin algıları arasında, kadrolu olarak çalışanlar lehine anlamlı farklılık bulunmaktadır. Bunun nedeni BİLSEM'lerin her eğitim öğretim yılında, bir önceki yıl gerçekleştirilen çalışmalar esas alınmak suretiyle proje tabanlı bir eğitim gerçekleştirmeye çalışması ve görevlendirme çalışan öğretmenlerin geçmiş yıllara ait çalışmalar ile ilgili belirsizlikler yaşaması olabilir. Kıdem durumuna göre ise BİLSEM öğretmenlerinin örgütsel değişime ilişkin algıları arasında anlamlı farklılık bulunmuş olup 11 yıl ve üstü kıdem grubundaki öğretmenler ile 1-5 yıl kıdem ve 6-10 yıl kıdem arasında 11 yıl ve üstü kıdem grubundaki öğretmenler lehine anlamlı bir fark olduğu bulunmuştur. Bunun nedeni BİLSEM'lerin çalışma prensiplerinin ve şartlarının örgün eğitim kurumlarından farklı olması ve bu farklılığın tecrübesiz öğretmenlerde belirsizlik ve bilinmezlik duygusu yaratması olabilir. Demirtaş (2012) ise benzer șekilde araştırmasında 21 yıl ve üstü kıdeme sahip öğretmenlerin örgütsel değişim algılarının diğer kıdem grubundaki öğretmenlere kıyasla daha olumlu olduğu sonucuna ulaşmıştır. Foster (1993) ile Akpınar ve Aydın (2007) ise araştırmalarında deneyimli öğretmenlerin en şüpheci, en isteksiz ve değişim çabalarına en az katılan grup olduğunu bulgulamışlardır. BİLSEM öğretmenlerinin örgütsel muhalefet algılarının "'katılıyorum" düzeyinde olduğu belirlenmiştir. Bunun nedeni BİLSEM müdürlerinin karar alma süreçlerinde katılımcı bir yapı ortaya koymamaları olabilir. Dağlı ve Ağalday (2014) ile Goodboy ve diğerleri (2008) araştırmalarında öğretmenlerin muhalif davranış algılarının düşük düzeyde olduğu sonucuna ulaşmıştır. Araştırma sonuçlarına göre BİLSEM öğretmenlerinin örgütsel muhalefet algıları arasında cinsiyet değişkeni açısından erkekler lehine anlamlı farklılık vardır. Bunun nedeni BİLSEM'lerde de geleneksel örgüt yaşantısının kadınlar üzerine yüklemiş olduğu görev itibariyle kadınların erkeklere göre karar süreçlerinde daha az etkin rol alması neden olabilir. Miceli ve Near (2006) ile Sims ve Keenan (1998) araştırmalarında erkeklerin kadınlara göre daha fazla muhalif davranışlar sergilediği sonucuna ulaşırken, Zhuang (2002) ise kadınların erkekle göre daha fazla muhalif davranışlar sergiledikleri sonucuna ulaşmıştır. BİLSEM öğretmenlerinin örgütsel muhalefet davranışlarına ilişkin algıları arasında medeni durumlarına ve öğrenim düzeylerine göre anlamlı farklılık yoktur. Sims ve Keenan (1998) da benzer şekilde araştırmalarında katılımcıların öğrenim düzeyi ile örgütsel muhalefet davranışları arasında anlamlı farklılık bulmazken; Özdemir (2013) ise araştırmasında lisansüstü eğitim muzunu olan öğretmenlerin lisans mezunu olan meslektaşlarına kıyasla daha fazla muhalif davranışlar sergilediği sonucuna ulaşmıştır. Örgütsel muhalefet algıları açısından çalışma şekline göre kadrolu BİLSEM öğretmenlerin lehine anlamlı bir farklılık belirlenmiştir. Öğretmenlerin çalışma şekline göre dikey muhalefet algı düzeylerinde anlamlı fark bulunurken, yatay muhalefet boyutunda anlamlı düzeyde fark bulunamamıştır. Bunun nedeni örgün eğitim gerçekleştiren kurumlara göre farklı bir çalıșma sistemi olan BİLSEM'lerin kadrolu öğretmenlerce geçmiş yıllarda tecrübe edilmiş olması ve kaynakların, sorumlulukların dağıtılmasında daha duyarlı olması olabilir. Ayrıca kıdem durumuna göre BİLSEM öğretmenlerinin örgütsel muhalefet davranışlarına ilişkin algı düzeyleri arasında anlamlı farklılık bulunmuş olup 11 yıl ve üstü kıdem grubundaki öğretmenler ile 15 yıl ve 6-10 yıl kıdeme sahip öğretmenler arasında 11 yıl ve üstü kıdem grubundaki öğretmenler lehine anlamlı bir fark olduğu görülmüştür. Aynı şekilde dikey muhalefet boyutunda 11 yıl ve üstü kıdem

129|P a g e

www.iiste.org 
grubundaki öğretmenler ile 1-5 yıl kıdeme sahip öğretmenler arasında 11 yıl ve üstü kıdem grubundaki öğretmenlerin lehine, yatay muhalefet boyutunda ise 11 yıl ve üstü kıdem grubundaki öğretmenler ile 1-5 yıl kıdem ve 6-10 yıl kıdeme sahip öğretmenler 11 yıl ve üstü kıdeme sahip öğretmenler lehine anlamlı bir fark olduğu görülmüştür. Bunun nedeni BİLSEM'lerde tecrübe sahibi olan, birçok proje ve etkinlikte aktif şekilde rol alan öğretmenlerin, tecrübesiz öğretmenlere göre onaylamadıkları örgütsel politikalara daha fazla karşı gelebiliyor olması olabilir. Kassing ve Dicioccio (2004) yaptıkları araştırmada mesleki kıdem ve örgütsel muhalefet arasında negatif yönlü bir ilişki bulmuşlardır. Sims ve Keenan (1998) tarafından gerçekleştirilen araştırmada ise örgütsel muhalefet ve mesleki kıdem arasında anlamlı farklılığa rastlanmamıştır. Araştırma sonuçlarına göre BİLSEM'de çalışan öğretmenlerin örgütsel değişim ve örgütsel muhalefet algıları arasında orta düzeyde pozitif yönde ve anlamlı bir ilişki olduğu bulunmuştur. Buna göre, öğretmenlerin örgütsel değişim algıları, örgütsel muhalefet algılarındaki değişimin \%62'sini açıkladığı; öğretmenlerin örgütsel değişim algıları ile dikey muhalefet algıları arasında pozitif yönde ve orta düzeyde bir ilişki sergilediği ve buna göre öğretmenlerin örgütsel değişim algıları, dikey muhalefet algılarındaki değişimin \%45'ini açıkladığı; öğretmenlerin örgütsel değişim algıları ile yatay muhalefet algıları arasında pozitif yönde ve orta düzeyde bir ilişski sergilediği ve buna göre öğretmenlerin örgütsel değişim algıları, yatay muhalefet algılarındaki değişimin \%53’ünü açıkladığı bulunmuştur. BİLSEM öğretmenlerinin bilgi ve becerilerinin sürekli değişmesi ihtiyacı ve bu değişmenin öğretmenlerin bireysel ihtiyaçlarını karşılaması noktasında eksik kalması öğretmenlerin muhalefet algılarındaki değişimin sebebi olabilir.

Araştırma bulgularına dayanarak aşağıdaki öneriler sunulabilir:

* BİLSEM öğretmenlerinin örgütsel değişime yönelik algı düzeylerinin orta düzeyde olduğu bulunmuş olup değişme ihtiyacının belirlenmesi, değişmenin planlanması, değişmenin uygulanması, değişimin felsefesi ve değişmenin değerlendirilmesi aşamaları sadece Merkez yöneticileriyle değil, bir ekip çalışmasıyla yürütülmelidir.

* BİLSEM'de çalışan kadın öğretmenlerin örgütsel değişim algılarını arttıracak önlemleri (iletişim, kararlara katılım, işbirliği) gerek Milli Eğitim Bakanlığg gerekse BİLSEM yöneticileri almalıdır.

* BİLSEM'lerde Milli Eğitim Bakanlığı tarafından kadrolu öğretmen istihdamı gerçekleştirilmelidir.

* BİLSEM'lerde çalışacak görevlendirme öğretmenlere eğitim öğretim yılı başında uyum ve destek eğitimleri verilmelidir.

* BİLSEM'lerde kadrolu veya görevlendirme yoluyla çalışacak öğretmenlerin meslekte deneyim sahibi öğretmenler arasından seçilmesi sağlanmalıdır.

* BİLSEM'lerde muhalefetin rekabet amaçlı değil yönetimle işbirliğine yönelik bir çalışma olduğu algısı oluşturulması adına güvene dayalı ilişkiler oluşturulmalıdır.

* BİLSEM’lerde gerçekleştirilecek her türlü değişimde bilgi akışının sağlıklı işlediği bir sistem yönetimlerce oluşturulmalıdır.

\section{Kaynakça}

Akpınar, B., ve Aydın, K. (2007). Eğitimde değişim ve öğretmenlerin değişim algıları, Eğitim ve Bilim, 32(144), 71-80.

Ataman, A. (2011). Özel gereksinimli çocuklar özel eğitime giriş, Ankara: Gündüz Eğitim ve Yayıncılık, 1929.

Balc1, A. (2000). İki binli y1llarda Türk Milli Eğitim sisteminin örgütlenmesi ve yönetimi, Kuram ve Uygulamada Ĕgitim Yönetimi, 24(1), 495-508.

Başar, A. (1996). Eğitim denetiminde eylem-zaman planlaması ve uygulaması, Ĕ̆itim Yönetim Dergisi, 2(4), 493-498.

$130 \mid \mathrm{P}$ a g e

Www.iiste.org 
International Journal of Scientific and Technological Research

ISSN 2422-8702 (Online), DOI: 10.7176/JSTR/6-06-09

Special Issue of Educational Sciences, Vol.6, No.6, 2020

Batu, S. ve Kırcaali İftar, G. (2006). Kaynaştırma, Ankara: Kök Yayıncılık.

Beycioğlu, K., ve Aslan, M. (2010). Okul gelişiminde temel dinamik olarak değişim ve yenileşme: Okul yöneticileri ve öğretmenlerin rolleri, Yüzüncü Yıl Üniversitesi Eğitim Fakültesi Dergisi, 7(1), 153-173.

Büyüköztürk, Ş., Çakmak, E., Akgün, Ö., Karadeniz, Ş. ve Demirel, F. (2008). Bilimsel araştırma yöntemleri, 1. Baskı, Ankara: Pegem Akademi.

Cavkaytar, A. ve Diken, İ. H. (2005). Özel eğitime giriş, Ankara: Kök Yayıncılık, s. 12, 23- 49.

Cenker, B. ve Macaroğlu Akgül, E. (2011). İlköğretim okullarında görev yapan öğretmenlerin, okulda değişim yönetiminin gerçekleştirilmesine bakış açılarının incelenmesi. Sakarya University Journal of Education, 1(1), 6-14.

Çağlar, Ç. (2013). Okulların değişime açıklık düzeyi ile öğretmenlerin örgütsel bağlılık düzeyi arasındaki ilişki, Adıyaman Üniversitesi Sosyal Bilimler Enstitüsü Dergisi, 6(15), 119- 150.

Çalık, T. (2003). Eğitimde değişimin yönetimi: Kavramsal bir çözümleme, Kuram ve Uygulamada Ĕ̈itim Yönetimi Dergisi, 9(4), 536-557.

Dağlı, A. (2015). Örgütsel muhalefet ölçeğinin Türkçe’ye uyarlanması: Geçerlik ve güvenirlik çalışması. Elektronik Sosyal Bilimler Dergisi, 14(53), 198-218.

Dağlı, A., ve Ağalday, B. (2014). Öğretmenlerin örgütsel muhalif davranış biçimlerine ilişkin görüşleri, Elektronik Sosyal Bilimler Dergisi, 112-128.

Dağlığlu, H. E. (2010). Üstün yetenekli çocukların eğitiminde öğretmen yeterlikleri ve özellikleri, Milli Eğitim Dergisi, 40(186), 72-84.

Davids, N., ve Waghid, Y. (2017). Inclusion/exclusion, tolerance and educational encounters, In Tolerance and Dissent within Education (pp. 135-150). Palgrave Macmillan, Cham.

Demirtaş, H. (2012). İlköğretim okullarının değişime açıklığı, İlköğretim Online, 11, 18-34.

Doğru, S. ve Uyar, M. (2012). Milli Eğitim Bakanlığı taşra örgütlerinin değişmeye direnme eğilimleri üzerine bir araştırma: Konya ili örneği, Buca Eğitim Fakültesi Dergisi, 32, 119-143.

Fidan, N., ve Erden, M. (1994). Eğitime giriş. Ankara: Meteksan Anonim Şirketi.

Foster, M. (1993). Urban African American teachers' views of organizational change: speculations on the experiences of exemplary teachers, Equity and Exellence in Education, 26, 16-24.

Garner, J. T. (2009). Strategic dissent: Expressions of organizational dissent motivated by influence goals, International Journal of Strategic Communication, 3(1), 34-51.

Goodboy, A. K., Chory, R. M., ve Dunleavy, K. N. (2008). Organizational dissent as a function of organizational justice, Communication Research Reports, 25, 255-265.

Güçlü, N., ve Şehitoğlu, E. T. (2006). Örgütsel değişim yönetimi, Atatürk Üniversitesi Kazım Karabekir Eğitim Fakültesi Dergisi, (13).

Helvacı, M. A. (2005). Ĕ̆itim örgütlerinde değişim yönetimi: İlke, yöntem ve süreçler. Ankara: Nobel Yayın Dağıtım.

$131 \mid \mathrm{P}$ a g e

www.iiste.org 
International Journal of Scientific and Technological Research

ISSN 2422-8702 (Online), DOI: 10.7176/JSTR/6-06-09

Special Issue of Educational Sciences, Vol.6, No.6, 2020

Helvacı, M. A., ve Kıcıroğlu, B. (2010). İlköğretim okullarının değişime hazır bulunuşluk düzeyleri (Uşak ili örneği). Akademik Bakış Dergisi, 21, 1-30.

Hornby, G. (2016). Inclusive special education, New York: Springer-Verlag. Karasar, N. (2007). Bilimsel araştırma yöntemi, Ankara: Nobel Yayın Dağıtım.

Kassing, J. W. (1998). Development and validation of the organizational dissent scale, Management Communication Quarterly, 12(2), 183-229.

Kassing, J. W. (2001). From the look of things: assessing perceptions of organizational dissenters, Communication Research, 21, 553-574.

Kassing, J.W. (2008). Consider this: a comparison of factors contributing to employees' expressions of dissent, Communication Quarterly, 56(3), 342-355.

Kassing, J. W. (2009). In case you didn't hear me the first time (an examination of repetitious upward dissent), Management Communication Quarterly, Vol. 22, no. 3, 416-436.

Kassing, J. W., ve Armstrong, T. A. (2002). Someone's going to hear about this: Examining the association between dissent-triggering events and employees' dissent expression, Management Communication Quarterly, 16(1), 39-65.

Kassing, J. W., ve Avtgis, T. A. (2001). Dissension in the organization as it relates to control expectancies, Communication Research Reports, 18(2), 118-127.

Kassing, J. W., ve DiCioccio, R. L. (2004). Testing a workplace experience explanation of displaced dissent, Communication Reports, 113-120.

Koçel, T. (2010). İşletme yöneticiliği, İstanbul: Beta Yayıncılık.

Kurşunoğlu, A., ve Tanrı̈ğğen, A. (2006). İlköğretim okulu öğretmenlerinin örgütsel değişmeye ilişkin tutumları, Pamukkale Üniversitesi Eğitim Fakültesi Dergisi, 20(20), 13-22.

Lawler, E. E. (2007). Built to change: How to achieve sustained organizational effectiveness, Strategic Direction, 23(4).

Leavitt, M. (2017). Reflecting on the journey: connecting the dots, In Your Passport to Gifted Education, Springer, Cham, 119-125.

Levent, F. (2016). Öğretmenlerin değişime hazır olma durumlarının farklı değiş̧kenlere göre incelenmesi, Eğitim Bilimleri Dergisi, 43(43), 117-134.

Lunenburg, F., ve Ornstein, A. (2013). Educational administration: Concepts and practice, Nelson Education.

MEB. (2016). Bilim ve Sanat Merkezleri Yönergesi, http://mevzuat.meb.gov.tr, Çevrimiçi, 14/11/2019.

MEB. (2018). Özel Eğitim Hizmetleri Yönetmeliği, http://mevzuat.meb.gov.tr, Çevrimiçi, 15/11/2019.

McMurray, A. J. (2007). The role of discussion and dissent in creating civic understanding, American Secondary Education, 49-58.

Miceli, M. P. ve Near, J. P. (2006). Individual and situational correlates of whistleblowing. Personnel Psychology, 2, 267-281.

132|P a g e

www.iiste.org 
International Journal of Scientific and Technological Research

ISSN 2422-8702 (Online), DOI: 10.7176/JSTR/6-06-09

Special Issue of Educational Sciences, Vol.6, No.6, 2020

Özdemir, M. (2013). Genel liselerde görev yapan öğretmenlerin örgütsel muhalefete ilişkin görüşleri (Ankara İli Örneği), Eğitim ve Bilim, 38(168).

Özdemir, S., ve Cemaloğlu, N. (2017). Örgütsel davranış ve yönetimi, Pegem Atıf İndeksi, 1- 698.

Robbins, S. P. (2005). Organizational behavior: Concepts, controversies, and applications. Upper Saddle River, NI: Prentice Hall.

Roberto, M. A. (2006). Why great leaders don't take yes for an answer. Pearson Education Inc., New Jersey.

Roda, A. (2015). Inequality in gifted and talented programs: Parental choices about status, school opportunity, and second-generation segregation, Springer.

Sabuncuoğlu, Z., ve Tüz, M. V. (2001). Örgütsel psikoloji. Alfa Basım Yayım Dağıtım.

Schlechty, P. C. (2011). Leading for learning: How to transform schools into learning organizations, John Wiley \& Sons.

Sims, R. L. ve Keenan, J. P. (1998). Predictors of external whistleblowing: organizational and intrapersonal variables, Journal of Business Ethics, 17, 411-421.

Türk Dil Kurumu (2018). http://www.tdk.gov.tr, (Çevrimiçi), 18.11.2019.

T.C. Anayasası (1982). http://www.tbmm.gov.tr/anayasa.htm, (Çevrimiçi), 15.11.2019.

Wright, M. D. (2013). The role of teamwork schema similarity and group atmosphere in perceptions of conversational appropriateness and organizational dissent, Master of Science College of Communication Texas Christian University, 6- 12-13-14-15.

Zhuang, J. (2002). Whistle-blowing and peer reporting: A cross-cultural comparison of Canadians and Chinese. Unpublished Master Thesis. Alberta: Lethbridge University, Kanada. 